Mississippi State University

Scholars Junction

5-3-2019

\title{
Impact of preventative fungicide practices on Mid-South soybean (Glycine max) grain development, quality, and economic return
}

Chase Alan Floyd

Follow this and additional works at: https://scholarsjunction.msstate.edu/td

\section{Recommended Citation}

Floyd, Chase Alan, "Impact of preventative fungicide practices on Mid-South soybean (Glycine max) grain development, quality, and economic return" (2019). Theses and Dissertations. 5055.

https://scholarsjunction.msstate.edu/td/5055

This Graduate Thesis - Open Access is brought to you for free and open access by the Theses and Dissertations at Scholars Junction. It has been accepted for inclusion in Theses and Dissertations by an authorized administrator of Scholars Junction. For more information, please contact scholcomm@msstate.libanswers.com. 
Impact of preventative fungicide practices on Mid-South soybean (Glycine max) grain development, quality, and economic return

\title{
By
}

\section{Chase Alan Floyd}

\author{
A Thesis \\ Submitted to the Faculty of \\ Mississippi State University \\ in Partial Fulfillment of the Requirements \\ for the Degree of Masters of Science \\ in Agronomy \\ in the Department of Plant and Soil Sciences
}

Mississippi State, Mississippi

May 2019 
Copyright by

Chase Alan Floyd

2019 
Impact of preventative fungicide practices on Mid-South soybean (Glycine max) grain development, quality, and economic return

By

Chase Alan Floyd

Approved:

J. Trenton Irby

(Major Professor)

Angus L. Catchot

(Minor Professor)

Thomas W. Allen

(Committee Member)

Darrin M. Dodds

(Committee Member)

Jason M. Sarver

(Committee Member)

Michael S. Cox

(Graduate Coordinator)

George M. Hopper

Dean

College of Agriculture and Life Sciences 
Name: Chase Alan Floyd

Date of Degree: May 3, 2019

Institution: Mississippi State University

Major Field: Agronomy

Major Professor: J. Trenton Irby

Title of Study: Impact of preventative fungicide practices on Mid-South soybean (Glycine max) grain development, quality, and economic return

Pages in Study: 49

Candidate for Degree of Masters of Science

The need for profitable soybean production practices gain continually with increasing input costs and reduced profit margins. Constant cultivar and product developments has resulted in limited current data available regarding the profitability of preventative fungicide applications and physiological benefits that can occur from these applications. Research was conducted during 2017 and 2018 to determine optimal fungicide application timing, while assessing multiple fungicide options and resulting effect on soybean grain yield, seed quality, and profitability. Additional research was conducted to determine optimal row spacing, planting date and fungicide application combinations to maximize soybean production profitability. These data suggest using multi-mode of action fungicide treatments increased soybean grain yield, regardless of application timing. These data also suggest, profitability from application of multimode of action fungicides can be observed at lower adjusted market prices. 


\section{DEDICATION}

I would like to dedicate this research and thesis to Eric Sullivan, Mark Nabors, and Sharon Watson. I would not be where I am today without their negative words and discouragement. Your failure at academics has provided me the motivation needed to excel in the classroom. This document and degree were accomplished to prove you three wrong. If my career path leads into the academic realm, I can assure you I will be tenfold the educators you

three are, were, or will ever be. Thank you for telling me I would not make it through a semester of college, and beating my head with a microphone and telling me it's hollow. Next, I would like to thank my biggest fan and grandmother Mary Jane Saikin. Without your immense support and weekly phone calls I wouldn't be the man I am today and every day. You've taught me the meaning of unconditional love. I would also like to dedicate the labor aspect of this research to my father Ben Floyd, who taught me the glory of hard work. Lastly, I dedicate this thesis to Mary Lou and Gerald Pendergraft, as well as, Stanley Saikin who have treated me like a blood son and grandson my entire life. You three have given me so much time, money, tears, and laughs. This research is my way of expressing my love for you all and thank you for sharing life with me by making me part of your family. 


\section{ACKNOWLEDGEMENTS}

I would like to acknowledge in the most humbling way possible my appreciation to the people who have shared this experience with me. First, my most sincere gratitude goes to Dr. Trent Irby, my major professor, for gambling on a kid who had not earned the right to enter graduate school, gave me the opportunity to prove people wrong, and advance my career. For half a decade you have shown me what it means to be an agronomist, and have set my goals higher than I would have ever done for myself. I will forever be in debt to you and hope I will make you proud as I carry your name with me throughout my career.

I would also like to thank Dr. Angus L. Catchot for showing me immense love and encouragement, as well as, opening many doors for me. I hope I become half of the successful entomologist as you are. I would like to also thank Dr. Darrin Dodds and Dr. Thomas Allen for all the guidance and laughs throughout my graduate career. I really enjoyed getting to know you more than just professors but as friends. Lastly, Dr. Jason Sarver who has aided me in more than just research and learning, but life as well. I appreciate the time and effort you all put into me and hope to be a name you speak of for years to come.

I would also like to thank Alanna Scholtes for her constant support and coordination of this research. You have provided me not only someone I am comfortable to ask the simplest of questions too, but a friend I will dearly miss speaking to daily. I especially want to thank Shane Carver, who taught me that I was capable of anything in this field, and spent hours making sure I was moving in the right direction. I would also like to thank Tristan Knight, Chase Kasper, 
Tanner Dinsmore, Zachary Treadway, and Jake Hall for all the sweat and hours you all spent aiding me in the field, I could not have accomplished this without every single one of you. The most significant factor I will take from this degree is the graduate students I have been involved with in my time at Mississippi State University, each one of these people has taught me how to be a better researcher and an even better friend. So, I would like to acknowledge Bradley "Nunchuck" Wilson, Brittany Etheridge, John North, Savana Davis, Angus Catchot III, Joey Williams, Jake "Lurch" Norris, Kyle Lassiter, Chad Abbott, Lucas Franca, Michael Plumblee, Nelson Corban, Jay Seale, and the rest of the MSU College of Agriculture graduate students.

Finally, I would like to thank Dr. Janice Dubien, Dr. Larry Falconer, and Dr. Josh Maples for their patience and effort they put forth in my understanding of statistical analysis, as well as, agricultural economics. I greatly appreciate the time they dedicated to aiding me in these data. 


\section{TABLE OF CONTENTS}

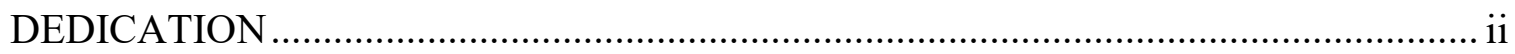

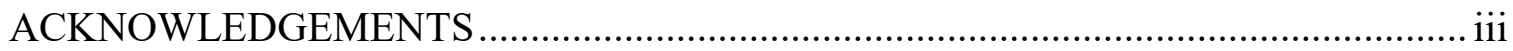

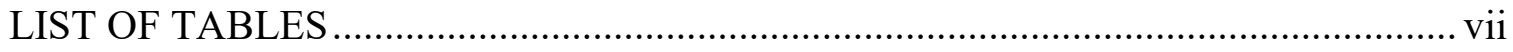

I. LITERATURE REVIEW AND INTRODUCTION .............................................

Soybean Growth and Development...........................................................

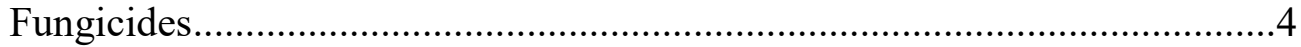

Soybean Yield and Seed Quality ...............................................................

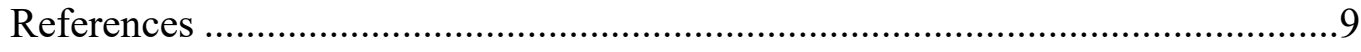

II. EVALUATION OF FUNGICIDE APPLICATION TIMING ON SOYBEAN

(Glycine max L.) GROWTH, DEVELOPMENT, AND YIELD........................12

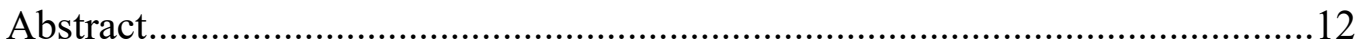

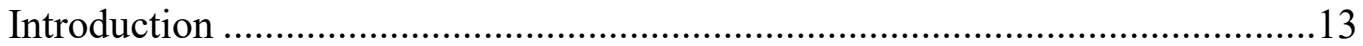

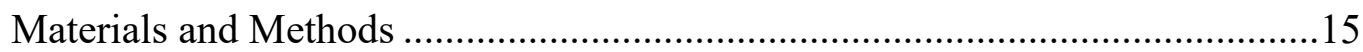

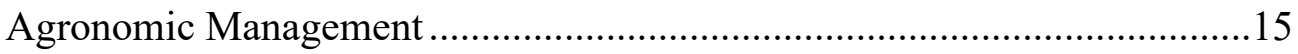

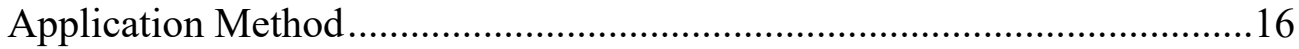

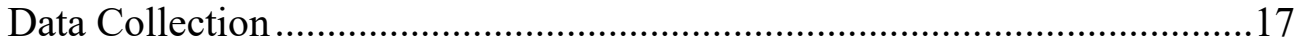

Statistical Analysis ..........................................................................

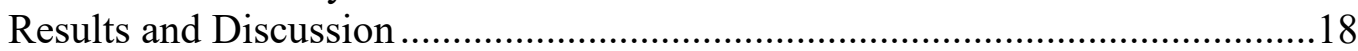

Plant Height, Node Count, Color and Vigor Differences, and Senescence

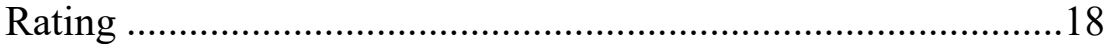

Soybean Yield \& Seed Mass ...........................................................19

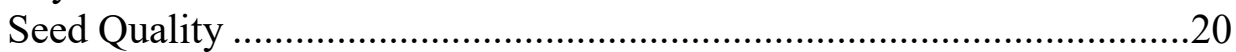

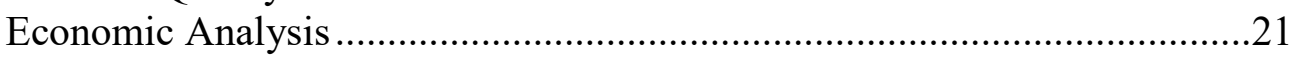

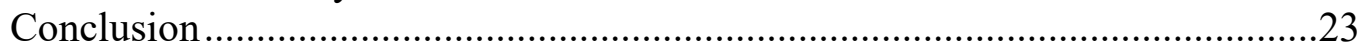

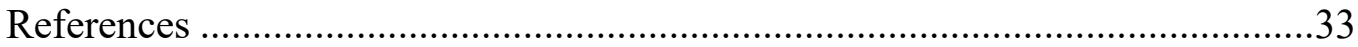

III. IMPACT OF ROW SPACING, PLANTING DATE, AND FUNGICIDE APPLICATION IN SOYBEAN (Glycine max) PRODUCTION ..........................35

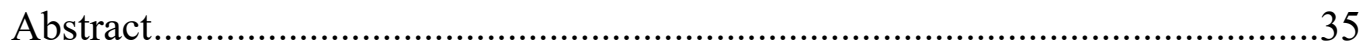

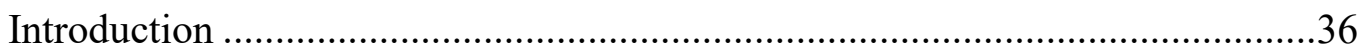

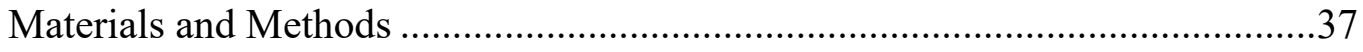

Agronomic Management ............................................................................38 


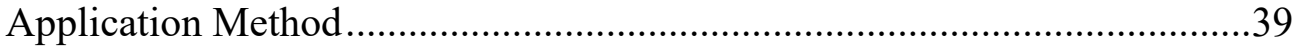

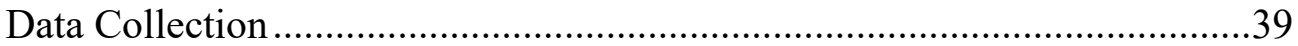

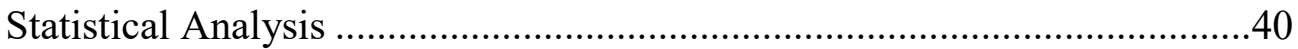

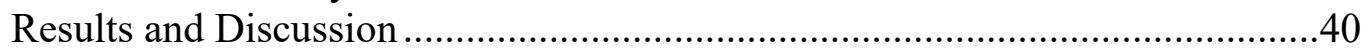

Plant Height, Node Count, Chlorophyll Recording, and Senescence

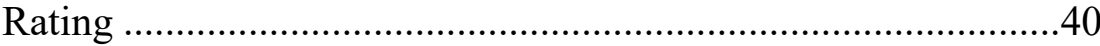

Post-Harvest Data Collection ..................................................................4

Soybean Yield \& Seed Mass ....................................................................41

Seed Quality .................................................................................42

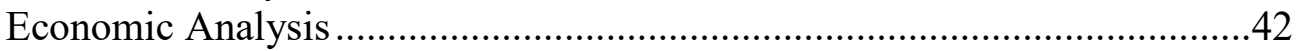

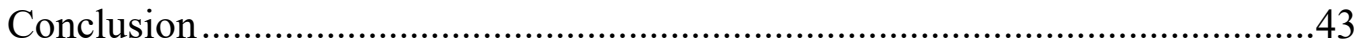

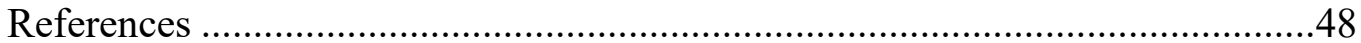




\section{LIST OF TABLES}

Table 2.1 Planting and application dates for Starkville and Stoneville, MS in 2017 and 2018.

Table 2.2 Analysis of variance $p$-values for growth parameters, yield, and seed quality measures for treatment combinations of fungicide and timing during 2017 and 2018

Table 2.3 Soybean seed mass and yield by fungicide treatment across all site years. ...27

Table 2.4 Soybean seed damage for application timing by fungicide treatment for all site years. .28

Table 2.5 Total cost per hectare for each fungicide treatment by application method...29

Table 2.6 Average returns, costs, and discounts for each fungicide treatment if applied by air in dollars per hectare. 30

Table 2.7 Average returns, costs, and discounts for each fungicide treatment if applied by ground in dollars per hectare.

Table 2.8 Average returns, costs, and discounts for each fungicide treatment if applied by ground in dollars per hectare.

Table 3.1 Planting and application dates of Starkville and Brooksville, MS in 2018 across all site years.

Table 3.2 Analysis of variance p-value for growth parameters, yield, and seed quality measured for treatment combinations of planting date, row spacing, and fungicide product during 2018 across all sites years.

Table 3.3 Effect of planting date on seed damage, seed mass, deductions and net return.47 


\section{CHAPTER I}

\section{LITERATURE REVIEW AND INTRODUCTION}

\section{Soybean Growth and Development}

Soybean [Glycine max (L.) Merr.] is recognized as the world's primary food source of protein in livestock feed, as well as, a large percentage of the world's vegetable oil supply (Wilcox, 2004). Soybean is the leading row crop commodity for the state of Mississippi. In the Mid-southern United States., including, Arkansas, Louisiana, and Mississippi, soybean production has a major impact on the stability of the agricultural economy. Mississippi producers planted an estimated 890,688 hectares in 2018 . Of the hectares planted, 886,639 hectares were harvested with an average yield of 3,663 kilograms per hectare (kg/h) (USDA-NASS, 2018), a new Mississippi yield record. Nationally, an estimated 35,706,882 hectares were planted with an average yield of $3,497 \mathrm{~kg} / \mathrm{h}$ with total revenue of an estimated $\$ 47,007,464,000$ (USDA-NASS, 2018). The state of Mississippi accounted for $2.5 \%$ of the total planted hectares nationally, and $2.2 \%$ of the total national revenue generated from soybean production (Anonymous, 2018a); USDA-NASS, 2018). Mississippi ranks $12^{\text {th }}$ nationally in terms of soybean production with an estimated total of 3,173,332,221 kilograms harvested during 2018 (Anonymous, 2018a). Soybean is considered a major export commodity in the U.S. market, making soybean production an important contributor to a grower's cropping system (Williams, 1999). The predecessor of modern soybean cultivars used in production today is native to the far eastern regions of Asia in China, Korea, Japan, and the eastern region of Russia (Purcell et al., 2014). The leguminous crop 
sown today, soybean is characterized as an annual dicot that stands erect, with a bushy growth habit, and alternating branching along the stem, with purple or white flowers developing on the stem during the plant's reproductive stages (Hymowitz and Singh, 1987).

Soybean growth habit is characterized by two main categories: determinate or indeterminate. A determinate cultivar will cease all growth on stem length and leaf production at the start, or soon after flowering (Bernard, 1972). Determinate cultivars are best suited for the Mid-southern U.S. due to the latitude resulting in shorter day/longer night periods, as well as warmer temperatures (Hoeft et al., 2000). Historically, determinate cultivars were planted later in the growing season, during late-May to Mid-July. Soybean planted in this time frame were often exposed to high temperatures and dry growing conditions late in the season, which reduced yield potential.

Agricultural practices such as the early soybean planting system (ESPS) made the planting of early maturing, indeterminate soybean cultivars more common (Heatherly et al., 1999). Soybean cultivars considered to be indeterminate in their growth habits continue stem elongation and foliage development even after flowering. These cultivars have extended flowering periods, which can be advantageous if the plant is presented with heat or drought stress later in the season. When compared with one another, these two growth habits do not differ in life cycles. Once flowering ceases, both determinate and indeterminate cultivars will begin pod fill, and abruptly decease shortly after (Bernard, 1972).

Soybean goes through two different growth stages throughout its course of life. These two stages are divided into sub-stages which enable the plant to be specifically categorized in terms of plant development. The first set of stages is defined as vegetative in which the plant focuses energy on foliage development. Once the seed is planted into the soil, imbibition begins 
resulting in swelling of the seed. When the seed absorbs an optimal amount of water, roughly $50 \%$ of the seed's weight, the radicle will emerge from a cracked seed coat. The radicle quickly develops into the soybean's primary root. The hypocotyl, tissue between the radicle and the cotyledons, elongates and creates a hook that pushes through the soil (Anonymous, 2015). Once emerged, the hypocotyl straightens and pulls the cotyledons from the soil, resulting in the emergence (VE) stage. After the VE stage, the seed will transfer into cotyledon (VC) stage as the initial leaves, or cotyledons unroll (Fehr et al, 1971). The next leaf to develop is the unifoliate, which is the plant's first node referred to by Fehr et al. (1971) V1. As V2 takes place, the plant begins to produce a compound leaf composed of three leaflets known as a trifoliate. Each new node is considered the next stage as the leaflets of the trifoliate are fully unrolled (Fehr et al, 1971). The remainder of the plant's vegetative stages are determined by the number of developed nodes and unrolled leaves, up to $\mathrm{V}(\mathrm{n})$. Once the first flower on the stem is present, the plant has attained the second set of stages known as the reproductive stages. During this time, energy produced by the plant is focused into flowers and fruiting. The reproductive stages are important with respect to yield, because during this time, seed number and size are determined (Pederson and Lauer, 2004). The existence of the first flower is known as beginning bloom (R1). Once the flowers begin to bloom in the upper two nodes of the plant, it has reached the full flowering (R2) stage. The plant will then progress into pod production and once pods in the four most upper nodes reach 12/25 centimeters $(\mathrm{cm})$ in length, beginning pod development (R3) has been accomplished. When pods on the upper four nodes have reached a length of $1.9(\mathrm{~cm})$, plants are said to be full pod (R4) (Fehr et al, 1971). The last of the reproductive stages are R5-R8. The full seed (R5) growth stage is identified by the first sign of visible seed formation inside a pod located on the upper four nodes of the plant. The full seed (R6) growth stage is achieved when 
seeds inside the pods develop to a point where the green seeds have completely filled the pod cavity. Maturing pods will begin to change their physical appearance by turning a yellowishbrown color. This outward change in pod color occurs in the R7 (beginning maturity) growth stage. The final growth stage, R8 (full maturity), is achieved once $50 \%$ of the pods have reached a mature color and contain mature seed in each pod (Fehr et al, 1971).

\section{Fungicides}

Soybean is susceptible to more than one hundred pathogens, thirty-five of these being economically important (Bowers and Russin, 1999). There are four main modes of action (MOA) for fungicides labeled for use in soybean. The quinone outside inhibitor (QoI) is a systemic group of fungicides primarily used as a preventative practice, and are known to aid in the prevention of spore germination (Bartlett et al., 2002; Grossman et al., 1999). The most recognized QoI is the family known as the strobilurins (Mueller, 2006). MOA is commonly used in cereal grains, corn and soybean. The QoI inhibits fungal mitochondrial respiration (Mueller, 2006). Once inhibited, the QoI stops energy production and causes the fungus to die. The QoI fungicides can be applied to foliage and enter the plant through the leaf tissue. These fungicides are known to be translaminar, which makes them successful at spreading across the leaf surface and even to the cuticle on the bottom of the leaves. The QoI's will show activity in one specific site in pathogens, which has contributed to the development of resistance to this mode of action (Anonymous, 2016). A total of 23 different plant pathogens have been reported to have developed resistance to QoI fungicides (Mueller, 2006). Preventative applications are the preferred practice for this particular mode of action (Mueller, 2006).

In the 1970's, the fungicide group known as demethylation inhibitors (DMI) which contains the triazole group of fungicides was introduced (Morton and Staub, 2008). The DMI 
group of fungicides is known for its high efficacy against powdery mildews, rusts, and several leaf spotting fungi (Anonymous, 2019). Triazoles are known to only inhibit one specific enzyme, the C14-demethylase. The enzyme is a contributing factor in the production of various sterols. These sterols are important for the plant to produce functional cell walls. For example, C14demethylase produces ergosterol which is used for membrane structure and function. Once the DMI impedes this enzyme, it causes the fungi to grow abnormally, ultimately inhibiting any further development. Unlike QoI's, DMI's have no effect on spore germination due to the high concentrations of sterol that spores contain. The DMI group of fungicides are commonly practiced as a preventative fungicide because once spores produce on the plant, triazoles are ineffective (Mueller, 2006). DMI's are extremely site-specific which can result in the development of resistance following multiple applications of the same product (Mueller, 2006). Due to the residual only being 7 to 10 days, DMI's are becoming obsolete as standalone products (Mueller, 2006). Applications of DMI's have also been reported to show some injury when applications are made in hot and dry environments (Mueller, 2006).

Methyl benzimidazole carbamate (MBC) is another common mode of action for fungicides in soybean production system. The MBC's are commonly divided into two main sections. The group recognized in soybean production is known by its common name thiophanate methyl (TM). Members of this class of fungicides target the fungal cytoskeleton and motor proteins (Anonymous, 2018b). More specifically, the MBC's target the $\beta$-tubulin assembly during mitosis. Resistance to MBC's is common and it is recommended that fungicides that contain MBCs be mixed with other MOA's when applied (Anonymous, 2018b).

The last MOA applied in soybean production systems is the succinate-dehydrogenase inhibitors (SDHI). The SDHI class of fungicides is known to affect cell respiration by targeting 
the succinate enzyme, which contributes to mitochondrial respiration and the mitochondria's electron transport chain (Keon et al., 1991). As of 2014, there was a high risk of resistance developing to the SDHI compounds, and resistance management is imperative when using this particular MOA (Anonymous, 2018b). The Fungicide Resistance Action Committee recommends that when applying a SDHI fungicide to potentially resistant targets, one must combine different MOA's that control the same pathogen.

Reducing the impact from soybean diseases is a major factor in soybean production in the Mid-southern U.S. From 2010 to 2014, there was an estimated \$ $149.83 \mathrm{ha}^{-1}$ economic losses when diseases were present in a field; however yield losses vary from field to field (Allen et al., 2017). Using preventative action increases the opportunity to maximize profits and sustainable production, whereas fungicides solely used as a curative action seldom, if ever, provide complete disease control (Bowers and Russin, 1999). In the southern U.S., fungicides are generally applied in a preventative fashion for yield loss prevention (Wrather and Koenning, 2006). Research in Texas reported preventative applications of trifloxystrobin increased yield, depending on soybean cultivar (Grichar, 2013). Producers are constantly looking for strategies to increase yield, due to the rising input costs and decline of profit margins. The application of foliar fungicides have been promoted for two reasons. First, for management of foliar pathogens that may negatively influence yield. Secondly, specific fungicide classes have been reported to produce physiological effects, such as increases in overall seed mass (Swoboda and Pedersen, 2009). Previous research in the Midwestern U.S. reported minimal information on the physiological effects of fungicides on soybean pertaining to yield increases when pathogens are present in the field, but most of the responses pertaining to yield enhancements have been in the absence of disease (Hanna et al, 2008). One of the major constraints of profitable soybean 
production in the Mid-southern U.S. is disease pressure (Bowers and Russin, 1999). During the growing season, the Mid-southern U.S. typically has ideal environmental conditions that contribute to pathogen development. The night time conditions are consistently warm, the humidity is high, and the dew periods are long. These factors all contribute to a rapid colonization of host plants by pathogenic fungi (Bowers and Russin, 1999).

\section{Soybean Yield and Seed Quality}

The integration of inputs into a soybean production system is the driving factor to optimize not only quality, but net return as well (Heatherly and Elmore, 2004). The foundation of this idea begins with successful cultivar selection. Though this is not the only important factor, proper cultivar selection is a major contributor to improving yield potential. Agricultural industries are constantly developing new traits to implement into their soybean germplasm. These traits can contribute management or tolerance to weeds, insects, and diseases that all can negatively affect yield. Furthermore, selecting a cultivar with an optimum disease package can increase profitability based off of individual producer's production systems and previous disease history. Selecting cultivars that are tolerant or even resistant to specific pathogens that are a common threat in a producer's production system, not always but can allow aid in yield preservation as well as seed quality by reducing stress from pathogens. While selecting a cultivar with an aggressive disease package is a strong input, disease management practices, such as crop rotation and tillage are still important management practices. Bowers and Russin (1999) stated the disease triangle is the backbone of disease development. The interaction of host plant, the pathogen, and the environment must be observed and managed strategically and accurately. Heatherly and Elmore (2004) state that genetic resistance is a sound strategy in most cases for disease management. While cultivar selection heavily influences the success of host plants 
within the disease triangle, prophylactic measures may be necessary if the environment becomes highly favorable for pathogen development.

In addition to managing for yield potential, quality of soybean seed harvested is also an important aspect in soybean production. Greater quality harvested seed aids in the reduction of discounts when grain is ready to be sold. The decline in quality allows the producer to increase the profitability of the production system. In the Mid-southern U.S., experts recommend foliar fungicides should be applied at the beginning pod (R3) and beginning seed (R5) growth stages to prevent seed diseases that can negatively influence overall seed quality, as well as, germination quality in seed production scenarios (Bowers and Russin, 1999; Wrather et al., 1995). Heatherly and Elmore (2004) state that harvest should commence as soon as seed reaches $14 \%$ moisture content, and equipment can enter the field. The ability to harvest soybean immediately when the desired moisture content occurs will ensure that minimal damage is inflicted by not only weathering, but also while undergoing the threshing process. Unfortunately, the climate of the Mid-southern U.S. does not permit timely harvest to be routine. If environmental conditions which promote seed decay are present in the final growth stages prior to physiological maturity, preventative fungicide application timing of R3 recommended by Moore et al. (1996) and Bowers and Russin (1999) may be too premature. With diseases being so prevalent in this region, it is imperative to prevent infection to the crop in hopes to reduce pathogen stress, which can reduce soybean yield and seed quality. New development of trait packages in updated soybean cultivars, need to be analyzed for their responses to various inputs commonly used in these production systems. Therefore, the need exists to determine the optimal application timings of preventative fungicides for yield preservation, as well as achievement of desirable grain quality in Mid-southern U.S. soybean production systems. 


\section{References}

Allen, T.W., Bradley, C.A., Sisson, A.J., Byamukama, E.,Chilvers, M.I., Cocker, C.M., Collins, A.A., Damicone, J.P., Dorrance, A.E., Dufault, N.S., Esker,P.D., Faske, T.R., Giesler, L.J., Grybauskas, A.P., Hershman, D.E., Hollier, C.A., Isakeit, T., Jardine, D.J., Kelly, H.M., Kermerait, R.C., Kleczewski, N.M., Koenning, S.R., Kurle, J.E., Malvick, D.K., Markell, S.G., Mehl, H.L., Mueller, D.S., Mueller, J.D., Mulrooney, R.P., Nelson, B.D., Newman, M.A., Osbourne, L., Overstreet, C., Padgett, G.B., Phipps, P.M., Price, P.P., Sikora, E.J., Smith, D.L., Spurlock, T.N., Tande, C.A., Tenuta, A.U., Wise, K.A., and Wrather, J.A. 2017. Soybean Yield LossEstimates Due to Diseases in the United States and Ontario, Canada, from 2010-2014. Plant Health Progress 2017 18:1, 19-27

Anonymous. 2019. Fungicides 101. Iowa State Extension.

https://www.extension.iastate.edu/sites/www.extension.iastate.edu/files/greene/Fungicide 101.pdf Accessed February 27. 2019

Anonymous. 2018a. Mississippi Ag Fact Book. Mississippi State University Division of Agriculture, Forestry, and Veterinary Medicine https://www.dafvm.msstate.edu/factbook.pdf January 11, 2019.

Anonymous. 2018b. Fungicide Mode of Action Code List. Fungicide Resistance Action Committee. http://www.frac.info/docs/default-source/publications/frac-codelist/frac_code_list_2018-final.pdf?sfvrsn=6144b9a_2 Accessed January 23, 2019.

Anonymous. 2015. Soybean Germination and Emergence. Ag Anytime. http://www.aganytime.com/soybeans/pages/article.aspx?name=Factors-that-AffectSoybean-Seed-Germination-and-Emergence\&fields $=$ article\&article=1412 Accessed March 28, 2017.

Bartlett, D. M., Clough, J. M., Godwin, J. R., Hall, A. A., Hamer, M., and Parr-Dobrzanski, B. 2002. The strobilurin fungicides. Pest Manag. Sci. 58:659-662.

Bernard, R.L. 1972. Two genes affecting stem termination in soybeans. Crop Sci. 12:235-239.

Bowers, G. R., and Russin, J.S. 1999. Soybean disease management. Pages 231-271 in Soybean Production in the Midsouth. L. G. Heatherly and H. F. Hodges, eds. CRC Press, Boca Raton, FL.

Fehr, W.R., Caviness, C.E., Burmood, D.T and Pennington, J.S. 1971. Stage Development Descriptions for Soybeans. Crop Sci. 11:929-930. 
Grichar, J. W. 2013. Soybean (Glycine max L.) response to fungicides in the absence of disease pressure. Int. J. Agron. Vol. 2013. Article ID. 561370.

https://doi.org/10.1155/2013/561370.

Grossman, K., Kwiatkowski, J., and Caspar, G. 1999. Regulation of phytohormone levels, leaf senescence and transpiration by the strobilurin kresoxim-methyl in wheat (Triticum aestivum). Pestic. Sci. 154:805-808.

Hanna, S. O., Conley, S. P., Shaner, G. E., and Santini, J. B. 2008. Fungicide application timing and row spacing effect on soybean canopy penetration and grain yield. Agron. J. 100:1488-1500.

Heatherly, L.G., Blaine, A., Hodges, H.F., Wesley, R.A., and Buehring, N. 1999. Variety selection, planting date, rowspacing, and seeding rate. Pages 41-52 in Soybean Production in the Midsouth. L. G. Heatherly and H. F. Hodges, eds. CRC Press, Boca Raton, FL.

Heatherly, L. G., and Elmore, R. W. 2004. Managing Inputs for Peak Production. Pages 451-536 In: H. R. Boerma, J. E. Specht, editors, Soybeans: Improvement, Production, and Uses, Agron. Monogr. 16. ASA, CSSA, and SSSA, Madison, WI.

Hoeft, R. G., Johnson, R. R., Nafziger, E. D., and Aldrich, S. R. 2000. Soybean as a crop modern corn and soybean production. First Edition. Pages. 31-39.

Hymowitz, T., and Singh, R. J. 1987. Soybeans: Improvement, Production, and Uses. Taxonomy and Speciation. Madison, WI Edition 2. NO. 16. Pages 49-93.

Keon, J. P.R., White, G.A, and Hargreaves, J.A. 1991. Isolation, characterization and sequence of a gene conferring resistance to the systemic fungicide carboxin from the maize smut pathogen, Ustilago maydis. Curr. Genet. 19:475-481.

Moore, S.H. 1996. Soybean seed quality. Louisiana Soybean Handbook. P16-23 in J. Hoenycutt (ed.). Pub. 2624. Louisiana State University, Baton Rouge, LA.

Morton, V., Staub, T. 2008. A Short Histroy of Fungicides. http://www.apsnet.org/publications/apsnetfeatures/pages/fungicides.aspx 
Mueller, D. 2006. Fungicides: QoI fungicides. Iowa State IPM. llhttp://www.ipm.iastate.edu/ipm/icm/2006/5-22/fungicides.html Accessed March 23, 2017.

Pedersen, P., and Lauer, J.G. 2004. Soybean growth and development in various management systems and planting dates. Agron. J. 2004. 44:508-515.

Purcell, L. C., Salermon, M., and Ashlock, L. 2014. Soybean Growth and Development. University of Arkansas. https://www.uaex.edu/publications/pdf/mp197/chapter2.pdf Accessed March 11, 2017.

Swoboda, C., and Pedersen, P. 2009. Effect of fungicide on soybean growth and yield. Agron. J. 101:352-355.

[USDA] U.S. Department of Agriculture. 2018. National Statistic Service. Soybean Acres Planted: Mississippi. Mississippi Department of Agriculture and Commerce. https://quickstats.nass.usda.gov/results/15746E91-6C28-3EFC-B949-54C45847EA60. Accessed 1/10/19.

Wilcox, J.R. 2004. Managing Inputs for Peak Production. Pages 451-536 In: H. R. Boerma, J. E. Specht, editors, Soybeans: Improvement, Production, and Uses, Agron. Monogr. 16. ASA, CSSA, and SSSA, Madison, WI.

Williams, B. 1999. Economics of soybean production in Mississippi. Pages 1-19 in Soybean Production in the Midsouth. L. G. Heatherly and H. F. Hodges, eds. CRC Press, Boca Raton, FL.

Wrather, J. A., Chambers, A.Y., Fox, J. A, Moore, W. F., and Sciumbato, G. L. 1995. Soybean disease loss estimates for the Southern United States, 1974-1994. Plant Dis. 79:10761079.

Wrather, J. A., and Koenning, S. R. 2006. Estimates of disease effects on soybean yields in the United States 2003-2005. J. Nematol. 38:173-180. 


\title{
CHAPTER II
}

EVALUATION OF FUNGICIDE APPLICATION TIMING ON SOYBEAN (Glycine max L.) GROWTH, DEVELOPMENT, AND YIELD.

\begin{abstract}
In the Mid-southern United States, the use of a preventative fungicide application at the beginning pod (R3) growth stage is a common practice for yield loss prevention in soybean. Previous research in Mississippi has reported a 201 to $402 \mathrm{~kg} \mathrm{ha}^{-1}$ yield increase from a preventative R3 fungicide application. The environment in the Mid-southern U.S. during the growing season can be favorable to the development of multiple diseases.

Experiments were conducted during 2017 and 2018 to determine the best application timing to apply fungicides at the R.R. Foil Plant Science Research Center near Starkville, MS in and 2018 at the Delta Research and Extension Center near Stoneville, MS. The experimental design consisted of a factorial arrangement of treatments within a randomized complete block. A total of 20 treatments included five growth stage based application timings, three different fungicide options, and a nontreated control for each assigned growth stage. Fungicide treatments included azoxystrobin, a combination of azoxystrobin + difenoconazole, and a combination of fluxapyroxad + pyraclostrobin + tetraconazole. Fungicides were applied in single applications at the R3, R4, R5, or R6 growth stages, along with a two-pass program treatment applied at R3 and again at R5 using a backpack sprayer equipped with a handheld boom containing Teejet Turbo Twinjet 11002 spray nozzles. Results indicate soybean receiving an application of azoxystrobin
\end{abstract}


+ difenoconazole or fluxapyroxad + pyraclostrobin + tetraconazole produced greater yields than the nontreated. An application azoxystobin application showed no benefit with respect to soybean yield compared to the nontreated control. In addition, the growth stage at which applications of fungicides are applied did not influence soybean yield.

\section{Introduction}

In recent years, a fungicide application at the beginning pod (R3) growth stage has been a common management practice in the Mississippi soybean production system. The R3 growth stage is achieved when soybean pods reach 1.27 centimeters $(\mathrm{cm})$ in length on one of the four most upper nodes of an indeterminate cultivar (Fehr et al, 1971). Previous research has reported a 201 to $402 \mathrm{~kg} \mathrm{ha}^{-1}$ yield increase from a preventative R3 application in $50-60 \%$ of the trials conducted since the early 2000s (Allen, 2015). Fungicide application from a preventative standpoint, along with other successful disease management practices, aid in reducing the effect of pathogens or the stress that the plant undergoes. When taking preventative action, producers are provided the opportunity to maximize profits and sustainable production (Bowers and Russin, 1999). An application of a fungicide is generally made in a preventative fashion for yield loss prevention in the Mid-southern U.S. (Wrather and Koenning, 2006). Other researchers in the Mid-southern U.S. reported that foliar fungicides applied at the R3 and full seed (R6) growth stages can reduce the risk of yield losses as a result of numerous foliar diseases (Backman et al., 1979; Horn et al., 1975). The R6 is growth stage occurs when the green seeds have completely filled the pod cavity (Fehr et al, 1971). Fungicide applications at the R3 growth stage in Mississippi have provided the advantages as a preventative measure, but suggestions state that these applications should be made under three circumstances. First, an application should be considered when continuous soybean have been planted in the field, where rotation practices are 
not implemented. Production systems in which rotation practices are not fulfilled may result in increased disease pressure for the following year. Wheat planted in the winter between two soybean crops is not considered a continuous soybean situation and this "rotation" practice, among others, can aid in the reduction of pathogens overwintering in the field. Secondly, applications are suggested to irrigated soybean fields, where the environment is more favorable for particular pathogens, due to greater humidity within the canopy potentially aiding in infection. Lastly, a preventative fungicide application in environments such as intensely managed, early planted soybean where yield potential is greater, is more likely to result in a positive return on investment (Allen 2015; Backman et al. 1979; Horn et al. 1975: Irby 2018 personal communication). Increases in yield have been observed when foliar fungicides are applied between the R3 and R6 growth stages (Rupe 1989; Rupe and Cochran 1990; Walters 1980). Consideration of multiple preventative fungicide applications in a single growing season have been contemplated. Implementation of a fungicide application at R3 followed by an R5 application also will most likely increase grain yield (Rupe, 1989; Walters, 1980; Rupe and Cochran, 1990). Henry et al. (2011) reported a 3\% yield increase following a foliar fungicide application at the full pod (R4) growth stage, or when the soybean pod has reached a length of $1.9 \mathrm{~cm}$. Yield increases of 195 to $370 \mathrm{~kg} \mathrm{ha}^{-1}$ were also observed in the Mid-western United States, when a strobilurin fungicide was applied alone or in combination with an insecticide. (Trybom and Jeshke, 2008). A strobilurin fungicide applied alone may provide up to 21 days of protection, but once the residual has passed, disease development can occur. The limited residual indicates that applications made early in the reproductive stages do not provide protection from infection for the remainder of the growing season (Allen 2015). In response to development of key pathogens' resistance to common fungicide chemistries, many companies have implemented 
multi-mode of action products or mixtures to reduce the risks associated with applying single mode of action chemistries to crops annually. However, the cost of fungicide products increases when multi-mode of action products are applied. Scherm et al (2009) found that multi-mode of action fungicide products provided greater yields and disease control than single mode of action products. Further research should be conducted to justify the implementation of more costly fungicide products as well as selecting the optimum growth stage at which products should be applied in hopes to positively influence soybean yield, and economic return. The objective of this research was to determine the optimum growth stage at which preventative fungicide applications containing multiple modes of action should occur in order to maximize soybean yield and profitability in irrigated soybean production systems.

\section{Materials and Methods}

Irrigated field experiments were conducted at one location in 2017, and two research facilities in 2018 growing season. Experiments locations included the R.R. Foil Plant Science Research Center near Starkville, MS $\left(33.474844^{\circ} \mathrm{N},-88.786186^{\circ} \mathrm{W}\right)$ on a Marietta Fine Sandy Loam soil (fine-loamy, siliceous, active, thermic Fluvaquentic Eutrudepts) and the MSU Delta Research and Extension Center near Stoneville, MS (33.402072 N, $\left.-90.925853^{\circ} \mathrm{W}\right)$ on a Sharkey Clay soil (Very-fine, smectitic, thermic Chromic Epiaquerts).

\section{Agronomic Management}

Land preparation for this experiment was adjusted to facilitate proper furrow irrigation practices. Soil samples were collected and MSU Extension recommended soil fertility management recommendations were followed at all locations. All other crop management 
practices, excluding foliar disease management, were executed based on MSU Extension suggestions.

An indeterminate maturity group IV cultivar was used in these experiments. In 2017, Pioneer P47T89R (Pioneer Hi-Bred International Inc, Johnston, IA) was utilized whereas, in 2018, Asgrow AG46X6 (Monsanto Company, St. Louis, MO) was utilized. Soybean cultivars selected for this experiment contained a strong disease package, which showed tolerance to pathogens common in Mississippi in order to evaluate soybean yield response in the absence of foliar disease presence. All experimental locations were seeded at a rate of 321,000 seeds $\mathrm{ha}^{-1}$ on $97.0 \mathrm{~cm}$ in plots measuring 12.2 meters in length. Seeds were planted at a depth of $2.8 \mathrm{~cm}$ using a John Deere MaxEmerge 2 planter equipped with John Deere MaxEmerge XP (Deere and Company World Headquarters, Moline, IL) row units. Irrigation was delivered using 12-inch by 7-mil flat lay polyethylene tubing (Delta Plastics, Little Rock, AR) to every other furrow in the field.

\section{Application Method}

Once the desired growth stage was reached, plots assigned to the corresponding growth stage a fungicide treatment was initiated. Fungicide application dates for when soybean reached various growth stages are presented in Table 2.1. Five different fungicide application timings were utilized which included beginning of pod development (R3), full pod (R4), beginning seed (R5), beginning seed (R6), and a two-pass program which received an initial application at R3 followed by an additional application at R5. Fungicides were applied to the center two rows of each four row plot using a $\mathrm{CO}_{2}$ - powered backpack sprayer at an operating pressure of $221 \mathrm{kPa}$ and an application volume of 140 liters $^{-1} \mathrm{a}^{-1}$ using TeeJet Turbo TwinJet flat spray nozzles (TTJ11002) (TeeJet Technologies Southeast, Tifton, GA). Three fungicide products were 
utilized and included azoxystrobin as Quadris॰ (Syngenta Crop Protection, Geensboro, NC), azoxystrobin + difenoconazole as Quadris Top SBX $\odot$ (Syngenta Crop Protection, Geensboro, NC), and the combination of fluxapyroxad, pyraclostrobin Priaxor $\odot$ (BASF, Raleigh, NC) and tetraconazole as Domark $\odot$ (Gowan, Yuma, AZ). Azoyxstrobin was applied at $109.3 \mathrm{~g}$ ai ha ${ }^{-1}$, azoxystrobin + difenoconazole applied each at a rate of $115 \mathrm{~g}$ ai ha $^{-1}$, and fluxapyroxad + pyraclostrobin + tetraconazole at rates of $48 \mathrm{~g}, 97 \mathrm{~g}$, and $53 \mathrm{~g}$ ai ha $^{-1}$, respectively. Additionally, each treatment contained a non-ionic surfactant at a rate of $0.25 \% \mathrm{v} / \mathrm{v}$. All treatments were applied at each application timing. An untreated control at each application timing was included for comparison purposes.

\section{Data Collection}

Prior to each application, the Canopeo App (Oklahoma State University, Stillwater, OK) to measure differences in color variation within the canopy, as well as ratings using the Trimble Greenseeker (Trimble, Sunnyvale, CA) which takes (NDVI) readings in order to measure vigor differences between treated rows. Similar ratings were collected 14 and 28 days after each fungicide applications to evaluate differences in canopy coverage and NDVI, as well as, possible phytotoxicity which has been observed following application of some fungicide chemistries. Preharvest plant heights were measured and final number of total nodes were recorded at the R5.5 growth stage. Previous research conducted by Mueller et al. (2009) found that soybean defoliation differed based on fungicide application. In order to further investigate soybean defoliation response to fungicide application, visual defoliation and green stem evaluations were recorded $0,3,7,14$, and 21 days following initial soybean leaf drop. The center two rows of each soybean plot was harvested uniformly using a Kincaid (Kincaid Equipment Manufacturing, Co., Haven, KS) 8-XP High Performance Multi-Crop Plot Combine. Soybean yield was adjusted to 
$13 \%$ standard moisture content. Once harvested, three 100 seed count sub-samples were collected from each harvested plot and weight was recorded to analyze seed mass. In 2018, all locations harvested samples for each plot in were delivered to Mid-South Grain Inspection (Stoneville, MS), a USDA certified seed facility to be inspected and evaluated for discounts from overall damage using a USDA certified CCC premium and discount guide (Anonymous, 2018).

\section{Statistical Analysis}

A factorial arrangement of treatments within a randomized complete block was utilized in this experiment with four replications of each treatment. Five timings and three fungicides were applied to soybean for a total of 20 treatments, which included non-treated controls for each corresponding growth stage. Statistical analysis was completed using the PROC GLIMMIX procedure in Statistical Analysis Software (v. 9.4, SAS Institute Inc., Cary, NC). Environment and replication were treated as random effects. Data were pooled over all locations and years, and means separated using Multiple Pairwise t-Tests at $\alpha=0.05$.

\section{Results and Discussion}

\section{Plant Height, Node Count, Color and Vigor Differences, and Senescence Rating}

No differences in soybean plant height or total node count were observed when comparing soybean treated with a foliar fungicide application to soybean receiving no fungicide (Table, 2.2). These findings are similar to those of Swoboda and Pedersen (2009) who observed no differences in soybean plant height and node production when fungicides were applied. The color and vigor differences of the overall canopy as well as those collected within the row were unaffected by fungicide applications. These data are contradictory to Bryson et al., (2000); Grossmann and Retzlaff, (1997); Grossman et al., (1999) in who found pyraclostrobin 
applications resulted in increased leaf greenness and chlorophyll content in treated plants. When pooled over all locations, there were no differences in defoliation or green stem retention after a fungicide application when compared to the untreated control.

\section{Soybean Yield \& Seed Mass}

Independently, fungicide application timing had no effect on grain yield $(P=0.27)$

(Table 2.2). In addition, no interaction of fungicide application timing and product were observed $(P=0.61)$ (Table 2.2). These data suggest that soybean receiving a single, preventative fungicide application as late as R6 will produce similar yield as soybean receiving the same application earlier (R3) in its life cycle. These data are contradictory to research published by Rupe (1989); Walters (1980); and Rupe and Cochran (1990), which found that a two-pass program is most likely to result in the greatest yield enhancements. Differences were observed in overall grain yield of soybean receiving application of different fungicide products $(P=0.02)$ (Table 2.2). Soybean that received a multi-mode of action fungicide treatment such as azoxystrobin + difenoconazole or fluxapyroxad + pyraclostrobin + tetraconazole resulted in a $3.7 \%$ and $3.9 \%$ increase in yield respectively, compared to soybean receiving no fungicide treatment (Table 2.3). When an application of azoxystrobin was applied to soybean, no yield increase was observed when compared to the nontreated control (Table 2.3). These data agree with Swooboda and Pedersen (2009) who found that yield increases were not observed on soybean receiving strobilurin applications. These data suggest that soybean yield increases following a preventative fungicide application are only observed when multi-mode of action fungicide treatments are applied, when compared to soybean receiving no fungicide. Seed weights measured through 100 seed sub samples suggest that when using multi-mode of action 
fungicide treatments on soybean, physiological changes can be observed. When compared to the nontreated control, a fungicide application of fluxapyroxad + pyraclostrobin + tetraconazole increased seed mass up to $3.6 \%$. Similarly, when azoxystrobin + difenoconazole were applied to soybean, the resulting seed mass increased by $2.7 \%(P=0.01)$ (Table 2.3). Applications of a stand-alone strobilurin did not significantly affect seed mass. There were no differences in seed mass observed following fungicide application at any growth stage $(P=0.73)$ (Table 2.2).

\section{Seed Quality}

In order to determine the impact of fungicide application timing or a two pass program may have on soybean seed quality, damage kernel total and heat damage from harvested samples were determined. Independently, timing of fungicide application $(P=0.36)$ (Table 2.2), nor product applied $(P=0.26)$ (Table 2.2$)$ resulted in differences in soybean seed quality. However, the interaction between fungicide application timing and product applied did suggest differences in damaged kernel totals. A two pass fungicide program offered no benefit with respect to seed damage. However, azoxystrobin and azoxystrobin + difenoconazole applied to R3 soybean resulted in greater seed damage than where no fungicide was applied. Azoxystrobin applied to $\mathrm{R} 4$ soybean resulted in similar seed damage as when azoxystrobin + difenoconazole was applied. Applications of fluxapyroxad + pyraclostrobin + tetraconazole resulted in the greatest percentage of damage kernels when applied at to R4 soybean, which resulted in damage kernels similar to those where no fungicide was applied. Applications of azoxystrobin and fluxapyroxad + pyraclostrobin + tetraconazole resulted in similar damaged kernels when applied to R6 soybean. Low damage rating observed on the R3 untreated soybean could be due to variations of microclimates within the field. Impact of microclimates were reported by Baldocchi et al. (1983) who stated temperature profiles can be affected by leaf orientation within the crop canopy. 
Soybean seed damage may be more severe in sub-sections of the field that may reach physiological maturity prior to other sub-sections (Allen, 2018). Once the plant reaches physiological maturity, and natural desiccation and senescence occurs, the protection of the seed provided by the pod is minimal. Due to lack of published data with respect to seed quality further research should be conducted to target the optimal strategy to reduce overall soybean seed damage.

\section{Economic Analysis}

All economic analysis from this experiment are based soybean off yield obtained from four locations across two years. Economic loss or gain for fungicide applications were based from the 2018 Mississippi Delta Planning Budget. Prices for the cost of fungicide application can be found on table 2.5 and 2.6. This includes price of treatment per hectare, cost of application method, as well as market price of soybean based on the corresponding prices when soybean plots were actually harvested. In order to accommodate Mississippi soybean producers both application methods were assessed. Average aerial and ground application costs were compared to diversify these data. When assessing net returns for aerial applications, calculations were based on yields achieved from ground methods in this experiment, due to difficulty of an aerial application of small plot research. Net returns were assessed by multiplying overall grain value and overall grain yield for each treatment, then average cost of application and total discounts were subtracted for each corresponding treatment and method of application (Table $2.7 \& 2.8$ ). Monetary values for each treatment based on individual yield. To account for soybean price discounts due to damage, each damage score was compared to the USDA Certified Premiums and Discounts, and a monetary price per $27.22 \mathrm{~kg}^{-1}$ for each treatment was assigned based on damage rating (Anonymous, 2018). The corresponding damage deductions were then multiplied 
by the overall grain yield to give a total value of deductions per treatment. The total deduction amount was then subtracted from the gross revenue after treatment cost to achieve a net return above fungicide treatment (Table 2.9). When analyzed according to market price at the day of harvest for soybean, only one fungicide product assessing aerial method showed profitability. Treatment using azoxystrobin + difenoconazole resulted in profitability of $\$ 10.40 \mathrm{ha}^{-1}$ compared to the untreated control (Table 2.9), on average. All other aerial treatments resulted in negative returns, on average, when compared to soybean profitability of the nontreated control (Table 2.9). Profitability from fungicide applications by airplane may begin to show profitability once market prices were adjusted for analytical purposes (Table 2.9). If soybean market prices are reaches to $\$ 0.33 \mathrm{~kg}^{-1}$, aerial application of a standalone azoxystrobin resulted in an average partial return of $\$ 1.18 \mathrm{ha}^{-1}$ (Table 2.9). Fluxapyroxad + pyraclostrobin + tetraconazole was not profitable unless market price was at least $\$ 0.37 \mathrm{~kg}^{-1}$, which resulted in an average gain of $\$ 0.77$ $\mathrm{ha}^{-1}$ (Table 2.9). These data suggest that at market prices of $\$ 0.30 \mathrm{~kg}^{-1}$ and below, applications of azoxystrobin does not lead to profitability and other options should be assessed if producers implement aerial fungicide applications. Conversely, application of fluxapyroxad + pyraclostrobin + tetraconazole, which resulted in the greatest yield did not result in net profit unless a soybean market price of $\$ 0.33 \mathrm{~kg}^{-1}$ or greater was obtained, when aerial applications are implemented.

Applications of azoxystrobin + difenoconazole by ground resulted in an average partial returns of $\$ 17.81 \mathrm{ha}^{-1}$ at soybean market price of $\$ 0.30 \mathrm{~kg}^{-1}$. Application of azoxystrobin alone resulted in an average $\$ 5.22 \mathrm{ha}^{-1}$ profitability at the soybean market price of $\$ 0.30 \mathrm{~kg}^{-1}$. Applications if fluxapyroxad + pyraclostrobin + tetraconazole require a market price of $\$ 0.33 \mathrm{~kg}^{-}$ ${ }^{1}$ in order to be profitable level for application by ground. Finally, all applications made in a two- 
pass program were determined to not be profitable at any assessed market price. Partial gains and profits for fungicide products used when comparing the two application methods are given in Table 2.9.

\section{Conclusion}

During the peak development stages of soybean production, the Mid-southern U.S.'s climate is ideal for foliar pathogen development. High humidity, minimal differentiation in night to day temps, and extended dew periods are potentially responsible for increased disease development (Bowers and Russin, 1999). Making preventative fungicide applications is not always a viable option, due to untimely rains during this portion of the growing season. Rainfall can cause preventative fungicide applications to be delayed to later growth stages than the current recommendations by not allowing machinery to be able to make the application at the desired timing. These data suggest that fungicide application can be delayed beyond current R3 with no adverse impact on soybean yield. However, these data were collected where no uniformly observable disease were recorded. These data also suggest that application of multimode of action fungicides can positively influence overall grain yield. Azoxystrobin, showed no yield enhancement when compared to soybean receiving no application. Suggesting that soybean producers may observe greater yield increases when applying multi-mode of action fungicides compared to none at all. These data highlight that residual protection from fungicide application may influence yield, but is not insurance to prevent losses associated with reduction in seed quality. Current Mississippi recommendations suggest that insecticides as well as irrigation should be terminated at the R6.5 growth stage, with exceptions based on specific insect species, such as the red banded stink bug (Piezodorus guildinii). Once the soybean plant reaches the R6.5 growth stage, the seed is fully separated from the pod wall. No management practices will 
influence physiological characteristics of the seed at this point. When comparing the average of each fungicides damage deduction, $\$ 0.05$ dollars $27.22 \mathrm{~kg}^{-1}$ separates the least damaging treatment from the nontreated. Azoxystrobin + difenoconazole-treated soybean resulted in the lowest damage level when compared to nontreated soybean from R4 to R6, as well as the two pass program and is the only treatment to result in profitability at the $\$ 0.30 \mathrm{~kg}^{-1}$ soybean selling price. Finally, these data suggest that application of azoxystrobin + difenoconazole can maximize soybean profitability in an irrigated environment with respect to yield. These data also suggest that a two pass program of a preventative fungicide application can be detrimental to profitable soybean production. 
Table 2.1 Planting and application dates for Starkville and Stoneville, MS in 2017 and 2018.

\begin{tabular}{|c|c|c|c|c|c|c|}
\hline \multirow{2}{*}{ Location } & \multirow{2}{*}{$\begin{array}{l}\text { Planting } \\
\text { Date }\end{array}$} & \multicolumn{5}{|c|}{ Application Date } \\
\hline & & $\mathrm{R}^{\mathrm{a}}$ & $\mathrm{R} 4^{\mathrm{a}}$ & $\mathrm{R} 5^{\mathrm{a}}$ & $\mathrm{R}^{\mathrm{a}}$ & $\mathrm{R} 3+\mathrm{R} 5^{\mathrm{a}}$ \\
\hline $\begin{array}{c}\text { Starkville }(\text { West })^{\mathrm{b}}, \mathrm{MS} \\
2017\end{array}$ & 03 May & 08 July & 14 July & 18 July & 14 August & $\begin{array}{l}08 \text { July }+18 \\
\text { July }\end{array}$ \\
\hline $\begin{array}{c}\text { Starkville }(\text { East })^{\mathrm{c}}, \mathrm{MS} \\
2018\end{array}$ & 04 May & 26 June & 13 July & 24 July & 8 August & $\begin{array}{l}26 \text { June }+ \\
24 \text { July }\end{array}$ \\
\hline $\begin{array}{c}\text { Starkville }(\text { West })^{\mathrm{b}}, \mathrm{MS} \\
2018\end{array}$ & 11 May & 06 July & 24 July & 14 August & 24 August & $\begin{array}{c}06 \text { July }+14 \\
\text { August }\end{array}$ \\
\hline $\begin{array}{c}\text { Stoneville (DREC) })^{\mathrm{d}}, \mathrm{MS} \\
2018\end{array}$ & 14 May & 10 July & 03 August & 07 August & 21 August & $\begin{array}{l}10 \text { July }+7 \\
\text { August }\end{array}$ \\
\hline
\end{tabular}

${ }^{a}$ timing of application based on growth stage

${ }^{b}$ R.R. Foil Plant Research Center West field

${ }^{c}$ R.R. Foil Plant Research Center East field

${ }^{\mathrm{d}}$ Delta Research Extension Center 
Table 2.2 Analysis of variance $p$-values for growth parameters, yield, and seed quality measures for treatment combinations of fungicide and timing during 2017 and 2018.

\begin{tabular}{cccccc}
\hline \multirow{2}{*}{ Treatment } & \multicolumn{5}{c}{ Prob $>\mathrm{F}$} \\
\cline { 2 - 5 } & Plant Height & Node Count & Seed Mass & Seed Damage & Yield \\
\hline Fungicide $^{\mathrm{a}}$ & 0.49 & 0.30 & 0.01 & 0.26 & 0.02 \\
Timing & 0.10 & 0.18 & 0.73 & 0.36 & 0.27 \\
$\begin{array}{c}\text { Fungicide by } \\
\text { Timing }\end{array}$ & 0.33 & 0.68 & 0.72 & 0.03 & 0.61 \\
\hline
\end{tabular}

a fungicide products applied in study

$\mathrm{b}$ timing of application based on growth stage

${ }^{\mathrm{c}}$ interaction between timing of application and fungicide product 
Table 2.3 Soybean seed mass and yield by fungicide treatment across all site years.

\begin{tabular}{|c|c|c|c|c|}
\hline \multirow{2}{*}{ Treatment } & \multicolumn{2}{|c|}{ Seed Mass ${ }^{\mathrm{a}}$} & \multicolumn{2}{|c|}{ Yield $^{b}$} \\
\hline & $\mathrm{g} / 100$ seed $^{\mathrm{a}}$ & Prob $>F^{a}$ & $\mathrm{~kg} / \mathrm{ha}^{\mathrm{b}}$ & Prob $>F^{b}$ \\
\hline Azoxystrobin & $16.21+2.1 \%$ & $a b$ & $4142.60+2.9 \%$ & $\mathrm{ab}$ \\
\hline $\begin{array}{l}\text { Azoxystrobin }+ \\
\text { Difenoconazole }\end{array}$ & $16.32+2.7 \%$ & $\mathrm{a}$ & $4177.23+3.7 \%$ & $\mathrm{a}$ \\
\hline $\begin{array}{c}\text { Fluxapyroxad + } \\
\text { Pyraclostrobin }+ \\
\text { Tetraconazole }\end{array}$ & $16.46+3.6 \%$ & $\mathrm{a}$ & $4187.70+3.9 \%$ & $\mathrm{a}$ \\
\hline Nontreated & 15.87 & $b$ & 4022.92 & $\mathrm{~b}$ \\
\hline
\end{tabular}

${ }^{a}$ average mass of three 100 count seed weights in grams. ( $p$-value 0.01$)$

${ }^{\mathrm{b}}$ grain yield in kilograms per hectare. ( $p$-value 0.02 ) 
Table 2.4 Soybean seed damage for application timing by fungicide treatment for all site years.

\begin{tabular}{|c|c|c|c|}
\hline \multicolumn{2}{|r|}{ Treatment } & \multirow{2}{*}{$\begin{array}{c}\text { Seed } \\
\text { Damage }^{\mathrm{a}}\end{array}$} & \multirow{2}{*}{ LSMeans $^{b}$} \\
\hline $\begin{array}{l}\text { Application } \\
\text { Timing }\end{array}$ & Fungicide & & \\
\hline R3 & Azoxystrobin & $16.1+26.8 \%$ & $\mathrm{a}$ \\
\hline R3 & Azoxystrobin + Difenoconazole & $16.4+28.3 \%$ & a \\
\hline R3 & $\begin{array}{c}\text { Fluxapyroxad }+ \text { Pyraclostrobin }+ \\
\text { Tetraconazole }\end{array}$ & $14.3+17.8 \%$ & abcd \\
\hline R3 & Nontreated & 11.8 & $\mathrm{dc}$ \\
\hline $\mathrm{R} 4$ & Azoxystrobin & $11.1-32.4 \%$ & bdc \\
\hline R4 & Azoxystrobin + Difenoconazole & $13.5-17.7 \%$ & abcd \\
\hline R4 & $\begin{array}{c}\text { Fluxapyroxad }+ \text { Pyraclostrobin }+ \\
\text { Tetraconazole }\end{array}$ & $16.1-1.9 \%$ & $\mathrm{a}$ \\
\hline $\mathrm{R} 4$ & Nontreated & 16.4 & $\mathrm{a}$ \\
\hline R5 & Azoxystrobin & $12.5-20.6 \%$ & abcd \\
\hline R5 & Azoxystrobin + Difenoconazole & $13.3-15.4 \%$ & abcd \\
\hline R5 & $\begin{array}{c}\text { Fluxapyroxad }+ \text { Pyraclostrobin }+ \\
\text { Tetraconazole }\end{array}$ & $13.2-1.9 \%$ & abcd \\
\hline R5 & Nontreated & 15.7 & $a b$ \\
\hline R6 & Azoxystrobin & $14.0-7.1 \%$ & abcd \\
\hline R6 & Azoxystrobin + Difenoconazole & $11.3-25.0 \%$ & $\mathrm{~d}$ \\
\hline R6 & $\begin{array}{c}\text { Fluxapyroxad }+ \text { Pyraclostrobin }+ \\
\text { Tetraconazole }\end{array}$ & $11.3-24.8 \%$ & $\mathrm{~cd}$ \\
\hline R6 & Nontreated & 15.1 & $\mathrm{abc}$ \\
\hline $\mathrm{R} 3+\mathrm{R} 5$ & Azoxystrobin & $14.0-12.6 \%$ & abcd \\
\hline $\mathrm{R} 3+\mathrm{R} 5$ & Azoxystrobin + Difenoconazole & $13.1-18.7 \%$ & abcd \\
\hline $\mathrm{R} 3+\mathrm{R} 5$ & $\begin{array}{c}\text { Fluxapyroxad }+ \text { Pyraclostrobin }+ \\
\text { Tetraconazole }\end{array}$ & $13.1-18.7 \%$ & abcd \\
\hline $\mathrm{R} 3+\mathrm{R} 5$ & Nontreated & 16.1 & $\mathrm{a}$ \\
\hline
\end{tabular}

${ }^{a}$ Seed damage provided by Mid-South Grain Inspection

${ }^{b}$ Seed damage with same letter groupings are not significantly different 
Table 2.5 Total cost per hectare for each fungicide treatment by application method.

\begin{tabular}{|c|c|c|c|c|c|c|c|c|c|}
\hline \multirow[b]{2}{*}{ Active Ingredient } & \multirow[b]{2}{*}{ Rate } & \multicolumn{4}{|c|}{ Application by air } & \multicolumn{4}{|c|}{ Application by ground } \\
\hline & & $\begin{array}{c}\text { Rate Cost } \\
\mathrm{ha}^{-1} \text { (a) }\end{array}$ & $\begin{array}{l}\text { Surfactant } \\
\text { Cost }^{\mathrm{a}}\end{array}$ & $\begin{array}{l}\text { Application } \\
\text { Cost }\end{array}$ & $\begin{array}{c}\text { Total } \\
\text { Cost hat }\end{array}$ & $\begin{array}{l}\text { Rate Cost } \\
\text { ha }^{-1(a)}\end{array}$ & $\begin{array}{l}\text { Surfactant } \\
\text { Cost }^{\mathrm{a}}\end{array}$ & $\begin{array}{c}\text { Application } \\
\text { Cost }\end{array}$ & $\begin{array}{c}\text { Total } \\
\text { Cost } \\
\text { ha }^{-1} \\
\end{array}$ \\
\hline Azoxystrobin & $\begin{array}{l}0.43 \mathrm{~L} \\
\mathrm{ha}^{-1}\end{array}$ & $\$ 31.71$ & $\$ 2.49$ & $\$ 16.05$ & $\$ 50.26$ & $\$ 31.71$ & $\$ 2.49$ & $\$ 8.65$ & $\$ 42.85$ \\
\hline $\begin{array}{l}\text { Azoxystrobin } \\
\text { (Two-Pass } \\
\text { Application) }\end{array}$ & $\begin{array}{l}0.43 \mathrm{~L} \\
\mathrm{ha}^{-1}+ \\
0.43 \mathrm{~L} \\
\mathrm{ha}^{-1}\end{array}$ & $\$ 63.42$ & $\$ 4.98$ & $\$ 32.10$ & $\$ 100.53$ & $\$ 63.42$ & $\$ 4.98$ & $\$ 17.30$ & $\$ 85.70$ \\
\hline $\begin{array}{l}\text { Azoxystrobin }+ \\
\text { Difenoconazole }\end{array}$ & $\begin{array}{l}0.51 \mathrm{~L} \\
\mathrm{ha}^{-1}\end{array}$ & $\$ 47.54$ & $\$ 2.49$ & $\$ 16.05$ & $\$ 66.10$ & $\$ 47.54$ & $\$ 2.49$ & $\$ 8.65$ & $\$ 58.68$ \\
\hline $\begin{array}{c}\text { Azoxystrobin }+ \\
\text { Difenoconazole } \\
\text { (Two-Pass } \\
\text { Application) }\end{array}$ & $\begin{array}{l}0.51 \mathrm{~L} \\
\mathrm{ha}^{-1}+ \\
0.51 \mathrm{~L} \\
\mathrm{ha}^{-1}\end{array}$ & $\$ 95.00$ & $\$ 4.98$ & $\$ 32.10$ & $\$ 132.19$ & $\$ 95.00$ & $\$ 4.98$ & $\$ 17.30$ & $\$ 117.28$ \\
\hline $\begin{array}{c}\text { Fluxapyroxad+ } \\
\text { Pyraclostrobin }+ \\
\text { Tetraconazole }\end{array}$ & $\begin{array}{l}0.58 \mathrm{~L} \\
\mathrm{ha}^{-1}\end{array}$ & $\$ 65.89$ & $\$ 2.49$ & $\$ 16.05$ & $\$ 87.41$ & $\$ 65.89$ & $\$ 2.49$ & $\$ 8.65$ & $\$ 77.03$ \\
\hline $\begin{array}{c}\text { Fluxapyroxad+ } \\
\text { Pyraclostrobin }+ \\
\text { Tetraconazole } \\
\text { (Two-Pass } \\
\text { Application) }\end{array}$ & $\begin{array}{c}0.58 \mathrm{~L} \\
\mathrm{ha}^{-1}+ \\
0.58 \mathrm{~L} \\
\mathrm{ha}^{-1}\end{array}$ & $\$ 131.78$ & $\$ 4.98$ & $\$ 32.10$ & $\$ 174.83$ & $\$ 131.78$ & $\$ 4.98$ & $\$ 17.30$ & $\$ 154.06$ \\
\hline
\end{tabular}

${ }^{a}$ Prices were determined using the Delta 2018 Planning Budget (Mississippi State University, Dept. of Agricultural Economics). 
Table 2.6 Average returns, costs, and discounts for each fungicide treatment if applied by air in dollars per hectare.

\begin{tabular}{|c|c|c|c|c|c|c|c|c|c|}
\hline \multirow{2}{*}{$\begin{array}{c}\text { Soybean Market } \\
\text { Price }\end{array}$} & \multicolumn{3}{|c|}{$\$ 0.30 \mathrm{~kg}^{-1}$} & \multicolumn{3}{|c|}{$\$ 0.33 \mathrm{~kg}^{-1}$} & \multicolumn{3}{|c|}{$\$ 0.37 \mathrm{~kg}^{-1}$} \\
\hline & $\begin{array}{c}\text { Total } \\
\text { Treatment } \\
\text { Cost } \\
\end{array}$ & $\begin{array}{c}\text { Total } \\
\text { Damage } \\
\text { Discount }\end{array}$ & $\begin{array}{c}\text { Net } \\
\text { Return }\end{array}$ & $\begin{array}{c}\text { Total } \\
\text { Treatment } \\
\text { Cost } \\
\end{array}$ & $\begin{array}{c}\text { Total } \\
\text { Damage } \\
\text { Discount }\end{array}$ & $\begin{array}{c}\text { Net } \\
\text { Return }\end{array}$ & $\begin{array}{c}\text { Total } \\
\text { Treatment } \\
\text { Cost } \\
\end{array}$ & $\begin{array}{c}\text { Total } \\
\text { Damage } \\
\text { Discount }\end{array}$ & $\begin{array}{c}\text { Net } \\
\text { Return }\end{array}$ \\
\hline $\begin{array}{l}\text { Nontreated } \\
\text { Control }\end{array}$ & 0 & 26.07 & $1,098.13$ & 0 & 26.07 & $1,238.56$ & 0 & 26.07 & $1,383.33$ \\
\hline Azoxystrobin & 50.26 & 17.91 & $1,095.94$ & 50.26 & 17.91 & $1,239.74$ & 50.26 & 17.91 & $1,387.99$ \\
\hline $\begin{array}{l}\text { Azoxystrobin } \\
\text { (Two-Pass } \\
\text { Application) }\end{array}$ & 100.53 & 17.51 & $1,040.03$ & 100.53 & 17.51 & 1,183.04 & 100.53 & 17.51 & $1,330.46$ \\
\hline $\begin{array}{l}\text { Azoxystrobin }+ \\
\text { Difenoconazole }\end{array}$ & 66.10 & 18.47 & $1,108.53$ & 66.10 & 18.47 & $1,255.93$ & 66.10 & 18.47 & $1,407.90$ \\
\hline $\begin{array}{c}\text { Azoxystrobin }+ \\
\text { Difenoconazole } \\
\text { (Two-Pass } \\
\text { Application) }\end{array}$ & 132.19 & 17.79 & $1,055.61$ & 132.19 & 17.79 & $1,204.40$ & 132.19 & 17.79 & $1,357.80$ \\
\hline $\begin{array}{c}\text { Fluxapyroxad }+ \\
\text { Pyraclostrobin }+ \\
\text { Tetraconazole }\end{array}$ & 87.41 & 18.00 & $1,085.46$ & 87.41 & 18.00 & $1,232.51$ & 87.41 & 18.00 & 1,384.11 \\
\hline $\begin{array}{c}\text { Fluxapyroxad }+ \\
\text { Pyraclostrobin }+ \\
\text { Tetraconazole } \\
\text { (Two-Pass } \\
\text { Application) }\end{array}$ & 174.83 & 20.85 & $1,025.10$ & 174.83 & 20.85 & $1,176.28$ & 174.83 & 20.85 & 1,332.12 \\
\hline
\end{tabular}


Table 2.7 Average returns, costs, and discounts for each fungicide treatment if applied by ground in dollars per hectare.

\begin{tabular}{|c|c|c|c|c|c|c|c|c|c|}
\hline \multirow{2}{*}{$\begin{array}{c}\text { Soybean Market } \\
\text { Price }\end{array}$} & \multicolumn{3}{|c|}{$\$ 0.30 \mathrm{~kg}^{-1}$} & \multicolumn{3}{|c|}{$\$ 0.33 \mathrm{~kg}^{-1}$} & \multicolumn{3}{|c|}{$\$ 0.37 \mathrm{~kg}^{-1}$} \\
\hline & $\begin{array}{c}\text { Total } \\
\text { Treatment } \\
\text { Cost } \\
\end{array}$ & $\begin{array}{c}\text { Total } \\
\text { Damage } \\
\text { Discount }\end{array}$ & $\begin{array}{c}\text { Net } \\
\text { Return }\end{array}$ & $\begin{array}{c}\text { Total } \\
\text { Treatment } \\
\text { Cost } \\
\end{array}$ & $\begin{array}{c}\text { Total } \\
\text { Damage } \\
\text { Discount }\end{array}$ & $\begin{array}{c}\text { Net } \\
\text { Return }\end{array}$ & $\begin{array}{c}\text { Total } \\
\text { Treatment } \\
\text { Cost } \\
\end{array}$ & $\begin{array}{c}\text { Total } \\
\text { Damage } \\
\text { Discount }\end{array}$ & $\begin{array}{c}\text { Net } \\
\text { Return }\end{array}$ \\
\hline $\begin{array}{c}\text { Untreated } \\
\text { Control }\end{array}$ & 0 & 26.07 & $1,098.13$ & 0 & 26.07 & $1,238.56$ & 7 & 26.07 & $1,383.33$ \\
\hline Azoxystrobin & 42.85 & 17.91 & $1,103.35$ & 42.85 & 17.91 & $1,247.15$ & 42.85 & 17.91 & $1,395.40$ \\
\hline $\begin{array}{l}\text { Azoxystrobin } \\
\text { (Two-Pass } \\
\text { Application) }\end{array}$ & 85.70 & 17.51 & $\mathbf{1 , 0 5 4 . 8 5}$ & 85.70 & 17.51 & $\mathbf{1 , 1 9 7 . 8 5}$ & 85.70 & 17.51 & $1,345.28$ \\
\hline $\begin{array}{l}\text { Azoxystrobin }+ \\
\text { Difenoconazole }\end{array}$ & 58.68 & 18.47 & $1,115.94$ & 58.68 & 18.47 & $1,263.34$ & 58.68 & 18.47 & $1,415.31$ \\
\hline $\begin{array}{c}\text { Azoxystrobin }+ \\
\text { Difenoconazole } \\
\text { (Two-Pass } \\
\text { Application) }\end{array}$ & 17.28 & 17.79 & $1,070.43$ & 17.28 & 17.79 & $1,219.22$ & 17.28 & 17.79 & $1,372.62$ \\
\hline $\begin{array}{c}\text { Fluxapyroxad }+ \\
\text { Pyraclostrobin }+ \\
\text { Tetraconazole }\end{array}$ & 77.03 & 18.00 & $1,092.87$ & 77.03 & 18.00 & $1,292.48$ & 77.03 & 18.00 & $1,391.52$ \\
\hline $\begin{array}{c}\text { Fluxapyroxad + } \\
\text { Pyraclostrobin }+ \\
\text { Tetraconazole } \\
\text { (Two-Pass } \\
\text { Application) }\end{array}$ & 154.06 & 20.85 & $1,039.92$ & 154.06 & 20.85 & $\mathbf{1 , 1 9 1 . 1 0}$ & 154.06 & 20.85 & $1,346.94$ \\
\hline
\end{tabular}


Table 2.8 Average returns, costs, and discounts for each fungicide treatment if applied by ground in dollars per hectare.

\begin{tabular}{|c|c|c|c|c|c|c|}
\hline Application Method & \multicolumn{3}{|c|}{ Aerial Application } & \multicolumn{3}{|c|}{ Ground Application } \\
\hline $\begin{array}{c}\text { Soybean Market Price } \\
\text { Product }\end{array}$ & $\$ 0.30 \mathrm{~kg}^{-1}$ & $\$ 0.33 \mathrm{~kg}^{-1}$ & $\$ 0.37 \mathrm{~kg}^{-1}$ & $\$ 0.30 \mathrm{~kg}^{-1}$ & $\$ 0.33 \mathrm{~kg}^{-1}$ & $\$ 0.37 \mathrm{~kg}^{-1}$ \\
\hline Nontreated Control $^{1}$ & ---- & ---- & ---- & ---- & ---- & ---- \\
\hline Azoxystrobin & $\begin{array}{c}2.19 \\
(70.80)\end{array}$ & $\begin{array}{c}1.18 \\
(78.30)\end{array}$ & $\begin{array}{c}4.66 \\
(86.10)\end{array}$ & $\begin{array}{c}5.22 \\
(70.80)\end{array}$ & $\begin{array}{c}8.59 \\
(78.30)\end{array}$ & $\begin{array}{c}12.07 \\
(86.10)\end{array}$ \\
\hline $\begin{array}{c}\text { Azoxystrobin } \\
\text { (Two-Pass Application) }\end{array}$ & $\begin{array}{l}-58.09 \\
(66.75)\end{array}$ & $\begin{array}{l}-52.52 \\
(73.48)\end{array}$ & $\begin{array}{l}-52.87 \\
(80.47)\end{array}$ & $\begin{array}{l}-43.27 \\
(66.75)\end{array}$ & $\begin{array}{l}-40.70 \\
(73.48)\end{array}$ & $\begin{array}{l}38.05 \\
(80.47)\end{array}$ \\
\hline Azoxystrobin + Difenoconazole & $\begin{array}{c}10.40 \\
(77.76)\end{array}$ & $\begin{array}{c}17.37 \\
(86.34)\end{array}$ & $\begin{array}{c}24.56 \\
(95.25)\end{array}$ & $\begin{array}{c}17.81 \\
(77.76)\end{array}$ & $\begin{array}{c}24.87 \\
(86.34)\end{array}$ & $\begin{array}{c}31.97 \\
(95.25)\end{array}$ \\
\hline $\begin{array}{l}\text { Azoxystrobin + Difenoconazole } \\
\text { (Two-Pass Application) }\end{array}$ & $\begin{array}{l}-42.52 \\
(85.73)\end{array}$ & $\begin{array}{l}-34.16 \\
(95.40)\end{array}$ & $\begin{array}{c}-25.53 \\
(105.40)\end{array}$ & $\begin{array}{l}-27.70 \\
(85.73)\end{array}$ & $\begin{array}{l}-19.34 \\
(95.40)\end{array}$ & $\begin{array}{c}-10.71 \\
(105.40)\end{array}$ \\
\hline $\begin{array}{c}\text { Fluxapyroxad + Pyraclostrobin }+ \\
\text { Tetraconazole }\end{array}$ & $\begin{array}{l}-12.67 \\
(64.02)\end{array}$ & $\begin{array}{c}-6.05 \\
(71.04)\end{array}$ & $\begin{array}{c}0.77 \\
(78.40)\end{array}$ & $\begin{array}{c}-5.26 \\
(64.02)\end{array}$ & $\begin{array}{c}1.36 \\
(71.04)\end{array}$ & $\begin{array}{c}8.18 \\
(78.40)\end{array}$ \\
\hline $\begin{array}{c}\text { Fluxapyroxad }+ \\
\text { Pyraclostrobin }+ \\
\text { Tetraconazole } \\
\text { (Two-Pass Application) }\end{array}$ & $\begin{array}{c}-73.03 \\
(66.90)\end{array}$ & $\begin{array}{c}-62.28 \\
(75.26)\end{array}$ & $\begin{array}{l}-51.22 \\
(84.01)\end{array}$ & $\begin{array}{c}-58.21 \\
(66.90)\end{array}$ & $\begin{array}{l}-47.46 \\
(75.26)\end{array}$ & $\begin{array}{c}-36.40 \\
(84.01)\end{array}$ \\
\hline
\end{tabular}




\section{References}

Allen, T. 2015. Automatic Soybean Fungicide Applications: Timing, Product Choice, Rates in Product Combination. http://www.mississippi-crops.com/2015/06/19/automatic-soybeanfungicide-applications-timing-product-choice-rates-in-product-combination/. Accessed $3 / 20 / 17$.

Allen, T., narrator. 2018. "Bald Pathologist Takes on Seed Quality" Mississippi Crop Situation podcast. Mississippi State Extension, 2018 Accessed 1/24/19.

Anonymous. 2018. Premiums and discounts corn, grain, sorghum, soybeans. United States Department of Agriculture Farm Service Agency. https://www.fsa.usda.gov/programsand-services/price-support/commodity-loan-rates/index. Accessed February 14, 2018.

Backman, P. A., Rodriquez-Kabana, R., Hammond, J. M., and Turlow, D. L. 1979. Cultivar, environment, and fungicide effects on foliar disease losses in soybeans. Phytopathology 69:562-564.

Baldocchi, D. D., Verma, S. B., and Rosenberg, N. J. 1983. Microclimate in the soybean canopy. Agricultural Meteorology 28:4:321-337.

Bowers, G. R., and Russin, J.S. 1999. Soybean disease management. Pages 231-271 in Soybean Production in the Midsouth. L. G. Heatherly and H. F. Hodges, eds. CRC Press, Boca Raton, FL.

Bryson, R.J., Leandro, L., and Jones, D.R. 2000. The physiological effects of kresoxim-methyl on wheat leaf greenness and the implications for crop yield. The Proc. of the BCPC Conf., Brighton, UK. 13-16 Nov. 2000. p. 739-749.

Fehr, W.R., Caviness, C.E., Burmood, D.T and Pennington, J.S. 1971. Stage Development Descriptions for soybeans. Crop Sci. 11:929-930.

Grossmann, K., Retzlaff, G. 1997. Bioregulatory effects of the fungicidal strobilurin kresoximmethyl in wheat (Triticum aestivum). Pestic. Sci.50:11-20.

Grossmann, K., Kwaltowski, J, and Caspar, G. 1999. Regulation of phytohormone levels, leaf senescence and transpiration by the strobilurin kresoxim-methyl in wheat (Triticum aestivum). J. Plant Physiol. 154:805-808.

Henry, R. S., Johnson, W. G., and Wise, K. A. 2011. The impact of a fungicide and insecticide on soybean growth, yield, and profitability. Crop Prot. 30:1629-1634.

Horn, N. L., Lee, F. N., and Carver, R. B. 1975. Effects of fungicides and pathogens on yields of soybeans. Plant Dis. Rep. 59:724-728. 
Irby, J. T. Personal Communications. November 15, 2018.

Mueller, T. A., Miles, M. R., Morel, W., Wright, D .L., Kemerait, R. C., Levy,C., and Hartman, G. L. 2009. Effect of fungicide and timing of application on soybean rust severity and yield. Plant Dis. 93:243-248.

Rupe, J. C. 1989. A comparison of foliar fungicides for the control of soybean diseases. Fayetteville: University of Arkansas. 15 p. (Agricultural Experiment Station. Report Series, 311).

Rupe, J. C., and Cochran, M. J.1999. Comparison of application timing of two foliar fungicides for the control of soybean diseases. Fayetteville: University of Arkansas, 1990. 20 p. (Arkansas Agricultural Experiment Station. Report series, 315).

Scherm, H., Christiano, R. S. C., Esker, P .D., Del Pont, E .M., and Godoy, C.V.2009. Quantitative review of fungicide efficacy trials for managing soybean rust in Brazil. Crop Prot 28:774-782

Swoboda, C., and Pedersen, P. 2009. Effect of fungicide on soybean growth and yield. Agron. J. 101:352-355.

Trybom, J., and Jeshke, M. 2008. Foliar Fungicides and Insecticide Effects on Soybean Yield. Pioneer Hi-Bred. https://www.pioneer.com/home/site/us/agronomy/library/foliarfungicide-insecticide-soybean-yield/ Accessed 3/25/17.

Walters, H. J., 1980. Soybean leaf blight caused by Cercospera kikuchii. Plant Dis. 64:961-962

Wrather, J. A., and Koenning, S. R. 2006. Estimates of disease effects on soybean yields in the United States 2003-2005. J. Nematol. 38:173-180 


\title{
CHAPTER III
}

\section{IMPACT OF ROW SPACING, PLANTING DATE, AND FUNGICIDE APPLICATION IN SOYBEAN (Glycine max) PRODUCTION}

\begin{abstract}
One of the major constraints to profitable soybean production is yield loss due to disease. The Mid-southern U.S. typically experiences environmental conditions that are conducive for pathogen development. It is common for producers in this region to apply fungicides to soybean at the R3 growth stage for yield loss prevention. Producers often question if crop establishment using a wide row pattern would alter environmental conditions within the crop canopy, ultimately influencing disease development and soybean yield response to a $\mathrm{R} 3$ preventative fungicide application. However, limited data exist to determine if yield response varies between differing row spacings. Therefore, the objective of this research was to evaluate the effects of preventative fungicide applications across multiple planting dates and row spacings on soybean growth, development, and yield.

These data suggest that early planted soybean resulted in greater yield compared to later planted soybean. No interactions were observed between row spacing, planting date, and fungicide product with respect to yield. Independently, no yield differences were observed regardless of row spacing or fungicide product. In regards to seed quality, soybean planted later resulted in lower soybean damage kernel totals.
\end{abstract}




\section{Introduction}

In the Mid-southern U.S., the Early Soybean Production System (ESPS) is a common practice for producers. The ESPS promotes planting earlier maturing cultivars during April and May rather than previous practices which consisted of maturity group (MG) VI and VII cultivars being planted in June. In Mississippi, MG IV and V cultivars accounted for more than $90 \%$ of all the soybean acres in 2014 (Anonymous, 2014). Variation in planting dates can also impact the control of harmful pests including numerous pathogens. A suggested disease management practice in soybean production is to alter planting date or maturity group, in order to allow the crop to reach critical development stages during a time when disease development does not typically occur. The decision to plant during an optimal planting window depends on many factors, including the common diseases in a specific region. Diseases such as anthracnose (Colletotrichum truncatum) can be avoided when planting early (Bowers and Russin, 1999). However, Heatherly et al. (1999) stated that the greatest risk of delaying planting until to mid-June is reduced yield potential due to shorter photoperiods. Planting date can also indirectly contribute to soybean seed quality in the Mid-southern U.S. Even though environment is the direct cause of reduced soybean seed quality, planting in the optimum planting window has been reported to decrease the losses associated with soybean seed quality. Heatherly and Elmore (2004) recommend that soybean should be harvested as soon as the seed reach $14 \%$ moisture to reduce risk of seed damage. However, this is not always feasible in the Mid-southern region of the U.S. as ESPS fields reach physiological and harvest maturity earlier in the growing season when untimely rains, high humidity and dew points may prevent heavy machinery from entering the field. The seed will then 
remain in the field until conditions are suitable for machine harvest, ultimately resulting in reduced seed quality given the unfavorable environmental conditions.

Along with planting dates, row spacing may also play a key role with respect to disease management. In the Mid-southern U.S. there are three common row spacings including, ultra-narrow $(38 \mathrm{~cm})$, narrow $(76 \mathrm{~cm})$, and wide rows $(97 \mathrm{~cm})$. Heatherly et al. (1999) stated that in the Mid-southern U.S., a yield increase is often observed when soybean planting occurs on rows spaced $50 \mathrm{~cm}$ or less. However, planting ultra-narrow row spacing is not always economically feasible due to the increase in production costs (Heatherly et al., 1999). Additional production costs are associated with equipment needed to achieve ultra-narrow production systems. Planting on narrower row spacing is a method to achieve more rapid canopy closure, ultimately contributing to a reduction in weed emergence. Conversely, widening the crop canopy may alter the temperature, relative humidity, and dew period within the microclimate, all of which can play a role in disease development (Bowers and Russin, 1999; Heatherly et al, 1999). Limited data exist justifying an adjustment of row spacing as a method for disease management in soybean (Bowers and Russin, 1999). Therefore, the objective of this research was to evaluate the effect of fungicide applications across multiple planting dates and row spacings on irrigated soybean growth, development, and yield.

\section{Materials and Methods}

Irrigated and non-irrigated field experiments were conducted at two Mississippi State University (MSU) research facilities during the 2018 growing season. These locations included two experiments at the R.R. Foil Plant Science Research Center near Starkville, MS 
(33.474844 $\left.\mathrm{N},-88.786186^{\circ} \mathrm{W}\right)$, on a Marietta fine Sandy Loam soil (fine-loamy, siliceous, active, thermic Fluvaquentic Eutrudepts) where the crop was irrigated and the MSU Black Belt Branch Experiment Station near Brooksville, MS $\left(33.257887^{\circ} \mathrm{N},-88.554029^{\circ} \mathrm{W}\right)$ in 2018, on a Brooksville Silty Clay soil (fine, smectitic, thermic Aquic Hapluderts) where the crop was non-irrigated.

\section{Agronomic Management}

Each experiment was planted with Asgrow AG46X6 (Monsanto Company, St. Louis, MO), an indeterminate, Roundup Ready 2 Xtend, maturity group IV soybean cultivar,. Three row spacings were implemented in the experiment consisting of wide $(97 \mathrm{~cm})$, narrow $(76 \mathrm{~cm})$ and ultra-narrow rows $(38 \mathrm{~cm})$. Soybean was planted using a planter consisting of Kincaid (Kincaid Equipment Manufacturing, Haven, KS) hydraulic telescoping tool bar equipped with four John Deere Max Emerge 5 row units, equipped with Precision Planting Vset electronic drive (Precision Planting, Tremont, IL), seeding rate was 321,100 seed per hectare (seed ha ${ }^{-1}$ ). Seed were planted during late-April and late-May representing early-season and late-season plantings, respectively. Fungicide treatments for each planting date and row spacing combination included azoxystrobin as Quadris $₫($ Syngenta Crop Protection, Geensboro, NC) applied at 109 grams active ingredient per hectare $\left(\mathrm{g}_{\text {ai }} \mathrm{ha}^{-1}\right)$, azoxystrobin + difenoconazole Quadris $\mathrm{SBX}_{\circledast}($ Syngenta Crop Protection, Geensboro, NC) applied each at a rate of $115 \mathrm{~g}_{\text {ai }} \mathrm{ha}^{-1}$, and the combination of fluxapyroxad, pyraclostrobin as Priaxor ${ }_{\circledast}\left(B A S F\right.$, Raleigh, NC) and tetraconazole as Domark ${ }_{\circledast}$ (Gowan, Yuma, AZ) at rates of 48, 97, and $53 \mathrm{~g} \mathrm{ai} \mathrm{ha}^{-1}$, respectively. Each fungicide application contained a non-ionic surfactant at a rate of $0.25 \% \mathrm{v} / \mathrm{v}$. In addition, soybean receiving no fungicide was included for each planting date and row spacing combination for comparison purposes. Combinations of row spacing and planting date were sown in plots measuring 12.2 
meters $(\mathrm{m})$ in length with a $6.1 \mathrm{~m}$ gap to separate replications, for a total of 24 treatments and 4 replications of each treatment. Furthermore, planting date and fungicide product were randomized within each row spacing, where all factors were fixed.

All locations consisted of a double disc followed by a do-all implement to prepare for suitable field conditions and diminish the presence of plant beds. Each location was left fallow in the fall and planted to a stale seedbed in the spring. Soil samples were collected each fall and fertility management practices were based on MSU Extension recommendations. Fertilizer applications were made in the fall of the previous crop year. All remaining crop management practices were based on MSU Extension recommendations.

\section{Application Method}

Once soybean reached the R4 growth stage, when the plant pods measured a $12 / 25 \mathrm{~cm}$ in length in the four upper most nodes, plots received its predetermined fungicide treatment was applied. Application dates are given in Table 3.1. Fungicide applications were made to the entire plot of the ultra-narrow row spacing, and the two center rows of the narrow and wide row spacing configurations. Applications were made using a $\mathrm{CO}_{2}-$ powered backpack sprayer at an operating pressure of $221 \mathrm{kPa}$ and application volume of $140 \mathrm{~L} \mathrm{ha}^{-1}$ using a TeeJet Turbo TwinJet flat spray tip TTJ11002 (TeeJet Technologies Southeast, Tifton, GA)

\section{Data Collection}

Prior to fungicide application, chlorophyll ratings were recorded using the Canopeo App (Oklahoma State University, Stillwater, OK) to measure greenness within the canopy. In addition, Trimble Greenseeker (Trimble, Sunnyvale, CA) was used to measure green matter within the row. Additional recordings were collected 14 and 28 days after fungicide applications 
to measure potential changes in green matter, including possible phytotoxicity which has been observed in some fungicide chemistries. Pre-harvest plant heights and node counts were recorded at the R5.5 growth stage. Once the first signs of natural senesce were observed, defoliation and green stem ratings were recorded. Soybean was harvested using a Kincaid 8-XP High Performance Multi-Crop Plot Combine (Kincaid Equipment, Haven, KS) outfitted with an onboard weigh system with the overall harvested width being $1.9 \mathrm{~m}$, or the center two rows of each plot. Soybean yield was adjusted to $13 \%$ standard moisture content. Once harvested, three 100 seed count sub-samples were collected from each harvested plot and weight was recorded to analyze seed mass. Finally, harvested samples for each plot were delivered to a USDA certified seed facility to be inspected and evaluated for discounts for total damage kernel and heat using a USDA certified CCC premium and discount guide (Anonymous, 2018).

\section{Statistical Analysis}

Treatments were arranged in a split-split-plot with the main plot factor being row spacing (3), sub-plot factor being planting date (2), and the sub-sub-plot factor being fungicide product (4), totaling 24 treatments. Data were pooled and analyzed from all locations, where location and replication were each treated as random. Statistical analysis was completed in PROC GLIMMIX using Statistical Analysis Software (SAS) version 9.4 (SAS Institute Inc., Cary, NC). Means were separated using Multiple Pairwise t-Test at an $\alpha=0.05$.

\section{Results and Discussion}

\section{Plant Height, Node Count, Chlorophyll Recording, and Senescence Rating}

No differences were observed in plant heights of soybean grown in the evaluated row spacings $(P=0.06)$ (Table 3.3). Soybean planted on a $97 \mathrm{~cm}$ row pattern achieved greater plant 
height compared to soybean planted in $38 \mathrm{~cm}$ rows. These observations are supportive to findings by Rahman (2013) who reported a decrease in row width increases overall plant height. When pooled across all site-years, final node number was not influenced by row spacing ( $P=0.86)$ (Table 3.2), planting date $(P=0.95)$ (Table 3.2), nor an interaction between the two variables $(P=0.31)$ (Table 3.2). Fungicide product also had no effect on overall node production $(P=0.93)$. These results are similar to those reported by Cox and Cherney (2011) who stated that row spacing had no effect on node development. Row spacing, planting date, nor fungicide product influenced canopy closure based on recordings of Canopeo measurements within the row. Observations from this experiment were not similar to the findings made by Bryson et al., (2000); Grossmann and Retzlaff, (1997); Grossman et al., (1999) observed that specific fungicide classes increased leaf greenness. No differences in defoliation and green stem retention were detected when analyzed by row spacing, planting date, and fungicide product, at any rating period.

\section{Post-Harvest Data Collection}

\section{Soybean Yield \& Seed Mass}

No interactions were observed between row spacing, planting date, and fungicide product ( $P=0.95$ ) (Table 3.2) with respect to soybean grain yield. Independently, the effect of row spacing resulted in no yield response $(P=0.68)$ (Table 3.2). Soybean yield did; however, respond to planting date $(P<0.01)$ (Table 3.2). Soybean planted in late-April resulted in greater yield compared to soybean planted in late-May. Soybean planted in the late-April averaged a yield of $8,892 \mathrm{~kg} \mathrm{ha}^{-1}$ whereas, soybean planted in the late-May planting averaged 7,647 $\mathrm{kg} \mathrm{ha}^{-1}$ soybean yield. These data support observations in various experiments where the ESPS provides a positive yield benefit (Bowers, 1995; Heatherly et al., 1999; and Heatherly, 2014). Lastly, 
fungicide product did not influence soybean yield $(P=0.46)$. With regards to seed mass, no differences were observed across all, row spacing, planting dates and fungicide applications. Observations made are contradictory to experiments conducted by Orlowski et al. (2016) who reported $4.6 \%$ seed mass increases following fungicide applications. When assessing yield data from this experiment, the location identified as Starkville West resulted in substantially lower yield overall.

\section{Seed Quality}

When analyzing seed quality, damage scores received from the elevator adjust the overall price the producer receives once sold. By analyzing a subsample of seed several factors are analyzed and appropriate deduction are applied. Differences in soybean seed quality were observed by planting date $(P<0.01)$ (Table 3.2). Soybean that was planted in late-May retained greater soybean seed quality compared to soybean planted in the late-April planting window. These findings are similar to Dorris (2001) who stated that early planted, early maturing cultivars used in the ESPS system can be adversely affected by seed decay resulting in a large portion of the crop with grain quality and, ultimately yield.

\section{Economic Analysis}

When assessing the economic gain or loss from management factors included in this experiment, data pooled across all locations were analyzed. Implementation of the ESPS has proven to be a successful practice in the Mid-southern U.S. for increasing overall grain yield. That being said the results from this experiment, along with others (Bowers, 1995; Heatherly et al., 1999; and Heatherly, 2014), suggest quality can be reduced when implementing the ESPS. Which poses the question that if the ESPS is being implemented in a soybean production system, 
will the yield benefits obtained from planting early outweigh the loss on seed quality in terms of profitability? Data collected from three locations in 2018 indicate an average loss of $\$ 64.22 \mathrm{ha}^{-1}$ (Table 3.4) when soybean were planted early at the average market price of $\$ 0.30 \mathrm{~kg}^{-1}$, when plots were harvested. During the conduct of this experiment, adverse weather conditions caused a delay in the ability to harvest plots in a timely fashion, ultimately resulting in a decline in seed quality. These unfavorable weather conditions impacted many Mississippi soybean producers, who suffered extreme losses in seed quality during the 2018 growing season. When soybean was planted during the late-May planting window, soybean damage deductions average $\$ 14.00 \mathrm{ha}^{-1}$ (Table 3.4). When comparing yield between the two, planting soybean in the late-April planting window resulted in a net return above fungicide treatment of $\$ 1134.46 \mathrm{ha}^{-1}$ (Table 3.4) while the net return above fungicide treatment of soybean planted in late-May was $\$ 990.71 \mathrm{ha}^{-1}$ (Table 3.4). Net return above treatment was achieved by taking the gross revenue and subtracting treatments costs as well as calculated damage discounts. Because a full implemented soybean budget has not been applied the previous is not considered net return. These data indicate that despite taking more severe soybean quality damage deductions, the yield benefit achieved in the ESPS compensates for the possible threats of damage deductions that may occur in this system.

\section{Conclusion}

No benefits from a fungicide application were observed at any row spacing or planting date, but further research should still be conducted to further investigate these factors contributions to yield response. This will allow variation in environment when conducting experiment another years, to strengthen the data set. The practice of the ESPS in Mississippi has been a profitable implementation to the Mississippi soybean production system. Results from this experiment supports recommendations for planting soybean during the optimal planting window. One area 
of concern within this practice is soybean reaching natural senescence during ideal environments for pathogen development, for example Phomopsis seed decay (Diaporthe longicolla) that can develop rapidly in these environmental conditions (Bowers and Russin, 1999). That being said, when implementing the ESPS soybean producers should spread out risks by planting differing maturity group soybean. This management option may allow multiple soybean fields to not achieve harvest maturity simultaneously. When heavy late season rainfall occurs like observed in Mississippi during 2018, spreading risks across varying degrees of soybean maturity may assist with avoiding severe damage deductions across an entire operation. This experiment concluded that environments where seed quality is taking greater losses, the yield benefit from planting in the optimal planting window can withstand harsh elevator discounts, and still remain the more profitable scenario. These data reassures the implementation of the ESPS production system is a successful and profitable practice. 
Table 3.1 Planting and application dates of Starkville and Brooksville, MS in 2018 across all site years.

\begin{tabular}{rccccc}
\hline & \multicolumn{2}{c}{ Early } & & \multicolumn{2}{c}{ Late } \\
\cline { 2 - 3 } Location (2018) & $\begin{array}{c}\text { Planting } \\
\text { Date }\end{array}$ & $\begin{array}{c}\text { Application } \\
\text { Date }\end{array}$ & & $\begin{array}{c}\text { Planting } \\
\text { Date }\end{array}$ & $\begin{array}{c}\text { Application } \\
\text { Date }\end{array}$ \\
\hline $\begin{array}{c}\text { Starkville (West), } \\
\text { MS }\end{array}$ & 30 April & 26 June & & 29 May & 14 August \\
$\begin{array}{c}\text { Starkville (East), } \\
\text { MS }\end{array}$ & 02 May & 22 July & & 29 May & 16 August \\
Brooksville, MS & 04 May & 13 July & & 26 May & 14 August \\
\hline
\end{tabular}


Table 3.2 Analysis of variance p-value for growth parameters, yield, and seed quality measured for treatment combinations of planting date, row spacing, and fungicide product during 2018 across all sites years.

\begin{tabular}{|c|c|c|c|c|c|}
\hline \multirow{2}{*}{ Treatment } & \multicolumn{5}{|c|}{ Prob $>$ F } \\
\hline & Plant Height $^{\mathrm{a}}$ & Node Count ${ }^{b}$ & Seed Mass ${ }^{\mathrm{c}}$ & Seed Damage $^{\mathrm{d}}$ & Yield $^{\mathrm{e}}$ \\
\hline Planting Date (PD) & 0.18 & 0.95 & 0.44 & 0.01 & 0.01 \\
\hline Row Spacing (RS) & 0.06 & 0.87 & 0.95 & 0.31 & 0.68 \\
\hline Fungicide Product (FP) & 0.96 & 0.94 & 0.54 & 0.23 & 0.47 \\
\hline$(\mathrm{PD}) *(\mathrm{RS})$ & 0.09 & 0.31 & 0.47 & 0.55 & 0.24 \\
\hline$(\mathrm{PD}) *(\mathrm{FP})$ & 0.72 & 0.69 & 0.41 & 0.75 & 0.10 \\
\hline$(\mathrm{RS}) *(\mathrm{FP})$ & 0.70 & 0.84 & 0.58 & 0.09 & 0.92 \\
\hline$(\mathrm{PD}) *(\mathrm{RS}) *(\mathrm{FP})$ & 0.95 & 0.99 & 0.24 & 0.90 & 0.95 \\
\hline
\end{tabular}

${ }^{a}$ height in centimeters recorded at the R6.5 growth stage

${ }^{\mathrm{b}}$ number of nodes recorded at R6.5 growth stage

${ }^{\mathrm{c}}$ average mass of three 100 count seed weights in grams

$\mathrm{d}$ average damage kernel total heat damage combined

${ }^{\mathrm{e}}$ grain yield in kilograms per hectare 
Table 3.3 Effect of planting date on seed damage, seed mass, deductions and net return.

\begin{tabular}{|c|c|c|c|c|c|}
\hline \multirow{3}{*}{ Treatment } & \multicolumn{3}{|c|}{ Agronomics } & \multicolumn{2}{|c|}{ Economics } \\
\hline & \multirow{2}{*}{$\begin{array}{c}\text { Seed } \\
\text { Damage }\end{array}$} & Seed Mass & Yield & \multirow{2}{*}{$\begin{array}{c}\text { Deduction } \\
\$ / \text { ha }\end{array}$} & \multirow{2}{*}{ Net Return } \\
\hline & & $\mathrm{g} / 100$ seed & $\mathrm{kg} / \mathrm{ha}$ & & \\
\hline$p$-value & 0.01 & 0.44 & 0.01 & ----- & ----- \\
\hline $\begin{array}{c}\text { Early } \\
\text { Planting } \\
\text { Date }\end{array}$ & $21 \mathrm{a}$ & $13.87 \mathrm{a}$ & $4030.64 \mathrm{a}$ & 64.22 & 1134.46 \\
\hline $\begin{array}{l}\text { Percent } \\
\text { Change }\end{array}$ & $\begin{array}{c}\uparrow \\
77.1 \% \\
\downarrow\end{array}$ & $\begin{array}{c}\uparrow \\
1.0 \% \\
\downarrow\end{array}$ & $\begin{array}{c}\uparrow \\
14.1 \% \\
\downarrow\end{array}$ & ------ & $\begin{array}{c}\uparrow \\
12.7 \% \\
\downarrow\end{array}$ \\
\hline $\begin{array}{c}\text { Late } \\
\text { Planting } \\
\text { Date }\end{array}$ & $4.8 \mathrm{~b}$ & $13.73 \mathrm{a}$ & $3460.67 \mathrm{~b}$ & 14.00 & 990.71 \\
\hline
\end{tabular}




\section{References}

Anonymous. 2016. Nematode Thresholds for Soybean. Mississippi State Extension. http://extension.msstate.edu/sites/default/files/topic-files/plant-diseases-and-nematodediagnostic-services/plant-diseases-and-nematode-diagnostic-services/soybean.pdf Accessed January 31, 2019

Anonymous.2014. Soybean production in Mississippi. Mississippi Agricultural and Forestry Experiment Station. http://msucares.com/crops/soybeans/recommend.html. Accessed January 31, 2019

Anonymous. 2018. Premiums and discounts corn, grain, sorghum, soybeans. United States Department of Agriculture Farm Service Agency. https://www.fsa.usda.gov/programsand-services/price-support/commodity-loan-rates/index. Accessed February 14, 2018

Bowers, G. R., Russin, J.S. 1999. Soybean disease management. Pages 231-271 in Soybean Production in the Midsouth. L. G. Heatherly and H. F. Hodges, eds. CRC Press, Boca Raton, FL.

Bowers, G.R. 1995. An early season production system for drought avoidance, J. Prod. 8:112119

Bryson, R.J., Leandro, L., Jones, D.R. 2000. The physiological effects of kresoxim-methyl on wheat leaf greenness and the implications for crop yield. The Proc. of the BCPC Conf., Brighton, UK. 13-16 Nov. 2000. p. 739-749

Cox, W.J., Cherney J.H. 2001. Growth and Yield Responses of Soybean Row Spacing and Seeding Rate. Agron. J. 103:123-128.

Dorris, E.A. 2001. Keeping the faith. Mississippi Farmer 11(12):12-14.

Grossmann, K., Retzlaff, G. 1997. Bioregulatory effects of the fungicidal strobilurin kresoximmethyl in wheat (Triticum aestivum). Pestic. Sci.50:11-20.

Grossmann, K., Kwaltowski, J, Caspar, G. 1999. Regulation of phytohormone levels, leaf senescence and transpiration by the strobilurin kresoxim-methyl in wheat (Triticum aestivum). J. Plant Physiol. 154:805-808.

Heatherly, L. G., R. W. Elmore 2004. Managing Inputs for Peak Production. Pages 451-536 In: H. R. Boerma, J. E. Specht, editors, Soybeans: Improvement, Production, and Uses, Agron. Monogr. 16. ASA, CSSA, and SSSA, Madison, WI.

Heatherly, L.G. 2014. Row Spacing Decisions. Mississippi Soybean Promotion Board. https://www.mssoy.org/uploads/2012/04/ROW-SPACING-DECISIONS-MAR20121.pdf accessed August 13, 2018. 
Heatherly, L. G., Blaine, A., Hodges, H.F., Wesley, R.A., Buehring, N. 1999. Variety selection, planting date, rowspacing, and seeding rate. Pages 41-52 in Soybean Production in the Midsouth. L. G. Heatherly and H. F. Hodges, eds. CRC Press, Boca Raton, FL.

Kinloch, R. 1992. Management of root-knot nematodes in soybean. p. 147-154. In L.G. Copping, M.B. Green, and 28 R.T. Rees (ed.) Pest management in soybean. Elsevier Science Publishers LTD, London, UK.

Orlowski, J. M., Haverkamp, B.J., Laurenz, R. G., Narburger, D. A., Wilson, E. W., Casteel, S. N., Conley, S. P., Naeve, S. L., Nafziger, E.D., Roozeboom, K. L., Ross, W. J., helen, K. D., Lee, C. D. 2016. High-Input Management Systems Effect on Soybean Seed Yield, Yield Components, and Economic Break-Even Probabiliries.Crop Science. Vol. 56 Pp. 1988-1990.

Riggs, R.D. 1992. Management of nematode problems on soybean in the United States of America. p. 128-136. In 48 L.G. Copping, M.B. Green, and R.T. Rees (ed.) Pest management in soybean. Elsevier Science Publishers LTD, 49 London, UK.

Robbins, R.T., Rakes, L., Elkins, C.R. 1994. Reniform Nematode Reproduction and Soybean Yield of Four Soybean Cultivars in Arkansas. Supplement Journal of Nematology. 24(4S):656-658.

Rhaman, M.M., Rhaman, M.M., Hossain, M.M. 2013. Effect of Row Spacing and Cultivar on the Growth and Seed Yield of Soybean (Glycine max [L.] Merrill) in Kharif-II season. The Agriculturists 11(1): 33-38 